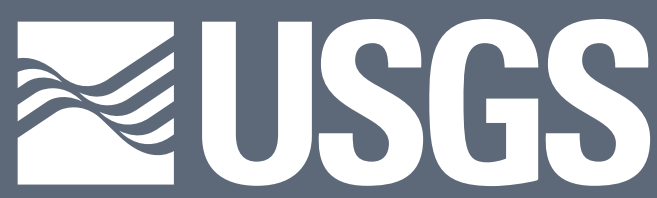

science for a changing world

\title{
RECONNAISSANCE INVESTIGATION OF CARIBBEAN EXTREME WAVE DEPOSITS - PRELIMINARY OBSERVATIONS, INTERPRETATIONS, AND RESEARCH DIRECTIONS
}

Robert A. Morton, Bruce M. Richmond, Bruce E. Jaffe, and Guy Gelfenbaum

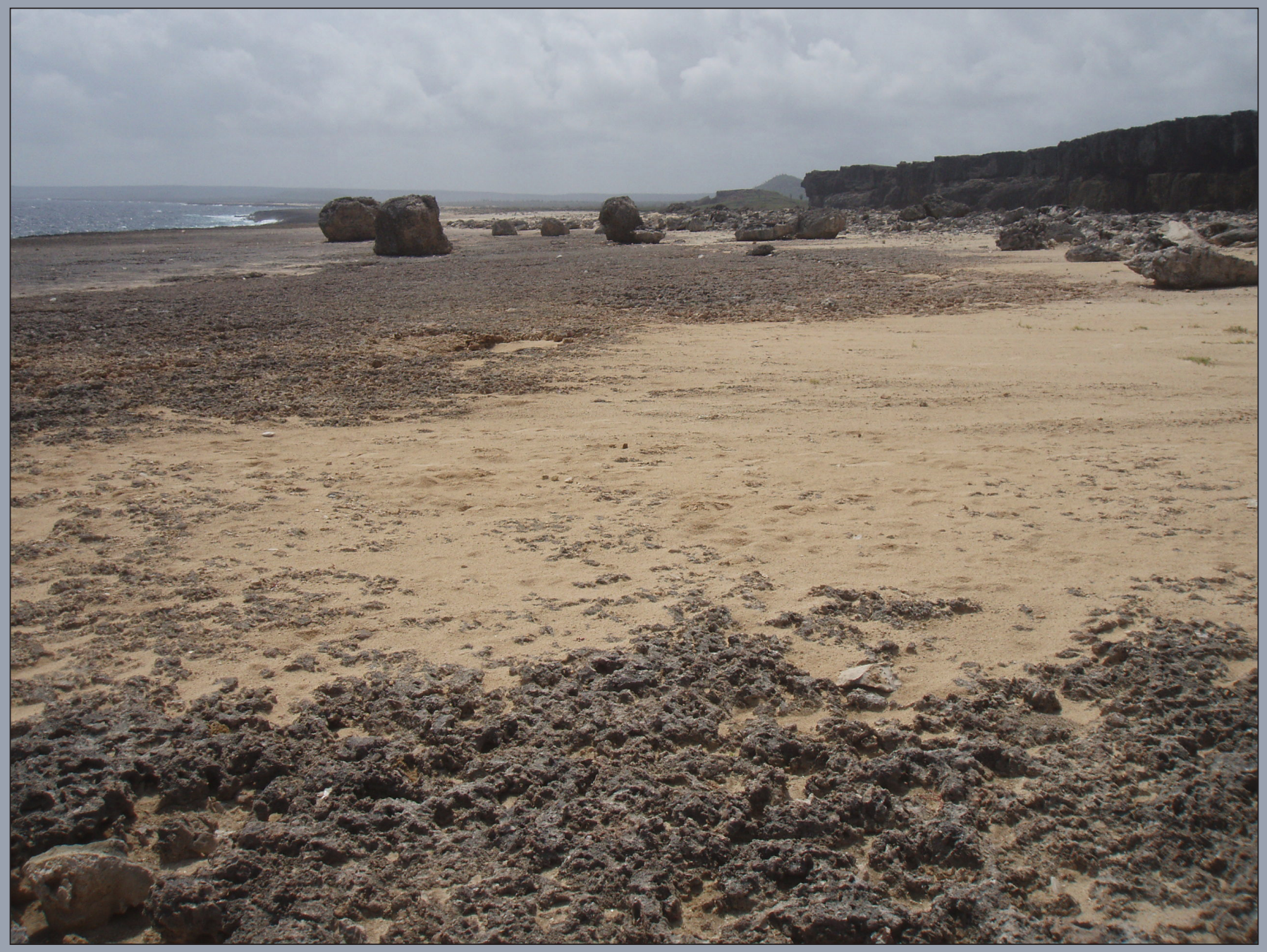

Open-File Report 2006-1293

U.S. Department of the Interior

U.S. Geological Survey 
Cover photograph - Panorama view on the north coast of Bonaire at Boka Kokolishi in March 2006 showing (from left to right), Caribbean Sea, modern sea cliff, scattered boulders and sand deposits on an elevated rock platform, and a paleo-seacliff. Wave swept zone and fresh sand deposits were products of Hurricane Ivan in September 2004. 


\section{RECONNAISSANCE INVESTIGATION OF CARIBBEAN EXTREME WAVE DEPOSITS - PRELIMINARY OBSERVATIONS, INTERPRETATIONS, AND RESEARCH DIRECTIONS}

Robert A. Morton', Bruce M. Richmond ${ }^{2}$, Bruce E. Jaffe ${ }^{2}$, and Guy Gelfenbaum ${ }^{3}$

'U.S. Geological Survey, 600 Fourth St. S., St. Petersburg, FL 33701

2U.S. Geological Survey, 400 Natural Bridges Drive, Santa Cruz, CA 95060 USA

3U.S. Geological Survey, 345 Middlefield Rd., Menlo Park, CA 94025 USA

Open-File Report 2006-1293

U.S. Department of the Interior

U.S. Geological Survey 


\section{Contents}

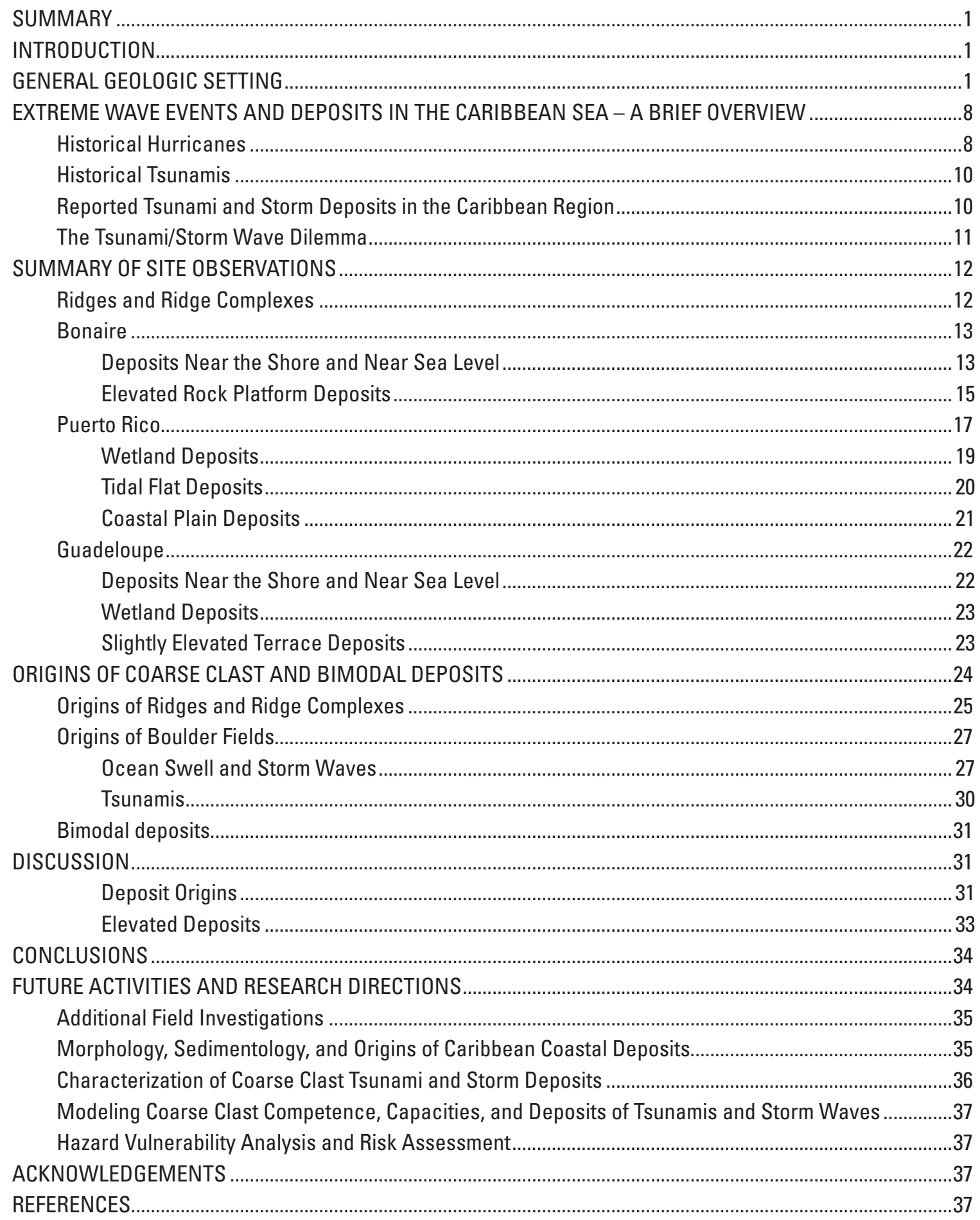




\section{Figures}

Figure 1. The Caribbean region showing locations of Puerto Rico, Guadeloupe, and Bonaire relative to the major

Figure 2. Locations of observation sites in Bonaire..................................................................................................

Figure 3. Locations of observation sites in Puerto Rico

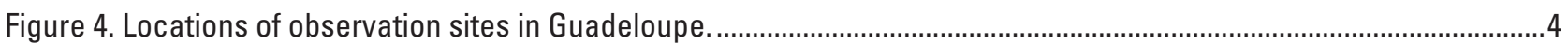

Figure 5. Tracks of all Atlantic tropical cyclones between 1851 and 2005

Figure 6. General topographic profile, morphology, and depositional setting of reef-rubble ridge complex......................13

Figure 7. Reef-rubble ridge complex near sea level on the western coast of Bonaire .......................................................14

Figure 8. Reef-rubble ridge complex near sea level on the eastern coast of Bonaire .............................................................15

Figure 9. Sharp-crested ridge near sea level on the northwestern coast of Bonaire constructed by Hurricane Lenny ..... 16

Figure 10. General topographic profile, morphology, and depositional setting of boulder field on rock platform................17

Figure 11. Rock platform on the eastern side of Bonaire............................................................................................ 18

Figure 12. Boulder field on rock platform on the eastern side of Bonaire showing landward decrease in clast size..........19

Figure 13. General topographic profile, morphology, and depositional setting of reef-rubble ridge complex on elevated

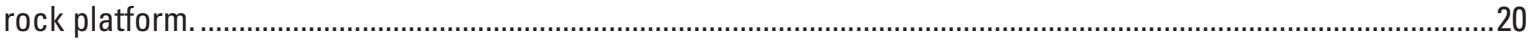

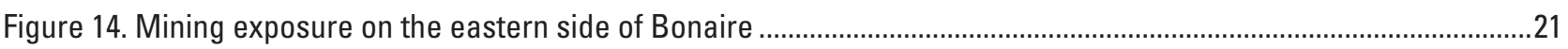

Figure 15. Panorama of landward sloping reef-rubble ridge complex on an elevated rock platform ..................................22

Figure 16. Mining pit on the seaward side of the reef-rubble ridge complex shown in fig. 15 ..............................................2

Figure 17. Apron of cobbles deposited by Hurricane Lenny on an elevated rock platform..................................................24

Figure 18. General topographic profile, morphology, and depositional setting of coastal plain and wetland setting..........25

Figure 19. Core of sediments beneath wetlands at Bajura, Puerto Rico ….....................................................................26

Figure 20. General topographic profile, morphology, and depositional setting of elevated terrace at Anse Ste. Marguerite

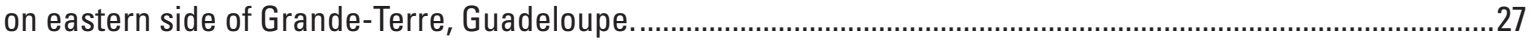

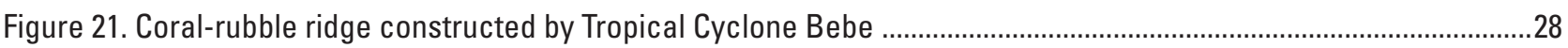

Figure 22. Coral-rubble ridge complex on Funafuti Atoll and Tropical Cyclone Bebe deposits .............................................29

Figure 23. Exposure of polymodal reef-derived sediments ................................................................................................30

\section{Tables}

Table 1. Descriptions and data collected at field observation sites in Bonaire.

Table 2. Descriptions and data collected at field observation sites in Puerto Rico ….................................................................

Table 3. Descriptions and data collected at field observation sites in Guadeloupe..................................................................... 


\section{SUMMARY}

This report presents an overview of preliminary geological investigations and recommended future research activities in the Caribbean region pertaining to coastal hazards with an emphasis on establishing tsunami risk for U.S. territories. Fieldwork was conducted in March 2006 on the islands of Bonaire, Puerto Rico, and Guadeloupe to evaluate the stratigraphic records of extreme wave deposits as possible indicators of paleotsunami recurrence. Morphological, sedimentological, and stratigraphic evidence indicate that shore-parallel coral rubble deposits composed of coarse clasts and sand that are 10s of meters wide and several meters thick are depositional complexes that have accumulated for a few centuries or millennia, and are not entirely the result of one or a few tsunamis as previously reported. The origins of boulder fields on elevated rock platforms of the Caribbean islands are more complicated than the origins of ridge complexes because boulder fields can be constructed by either storm waves or tsunamis. What is needed now for more conclusive interpretations is a systematic sedimentological approach to deposit analysis and a set of criteria for distinguishing between coarse clast storm and tsunami deposits. Assembling more field data from other Caribbean islands, analyzing stratigraphic deposits on Puerto Rico and Bonaire, and investigating boulder field deposits resulting from a historical tsunami can accomplish this. Also needed are improved sediment transport models for coarse clasts that can be used to estimate the competence and capacity of tsunamis and storms waves and to determine whether a deposit likely was created by a tsunami or extreme storm. Improved models may also be useful for reconstructing the magnitude of extreme wave events.

\section{INTRODUCTION}

The December 26, 2004 Indian Ocean earthquake and tsunami were grim reminders of the devastating forces associated with these catastrophic events and their ability to cause widespread death and destruction. Since then government agencies, scientists, and engineers have focused their attention on other regions of the world where active tectonic processes increase the probability of generating tsunamis that could cause loss of life and property. One such region is the Caribbean Sea and surrounding islands where historical earthquakes, volcanic eruptions, and associated tsunamis have been reported (Lander and others, 2002). The increased public awareness of coastal hazards after the devastating 2004 tsunami follows a general scientific trend in recent years to reconstruct histories of tsunami hazards from the sedimentary record, especially for areas where the written histories are short or incomplete.

This report summarizes our observations and preliminary interpretations of coastal sediments deposited by extreme waves that were investigated on the islands of Bonaire, Puerto Rico, and Guadeloupe (Figs. 1-4). This work was conducted in early 2006 as part of a regional reconnaissance of possible paleotsunami deposits in the Caribbean region. We were accompanied in Bonaire by Anja Scheffers and Dieter Kelletat (University of Duisburg-Essen), in Puerto Rico by Juan Carlos Moya (Texas General Land Office), and in Guadeloupe by Narcisse Zahibo (Université Antilles Guyane). These individuals have published tsunami research for the respective islands (see references), they were familiar with the local settings, and they served as field guides to coastal sites where tsunami deposits might be preserved. The field methods and types of data collected at all sites included GPS locations, photographs, and field notes, while at some sites additional data were collected in the form of shallow trenches, narrow push cores, and some sediment samples (Tables 1-3).

\section{GENERAL GEOLOGIC SETTING}

The Caribbean Sea is one of the active tectonic regions of the Earth. Earthquakes, volcanic eruptions, and submarine landslides, which are all 


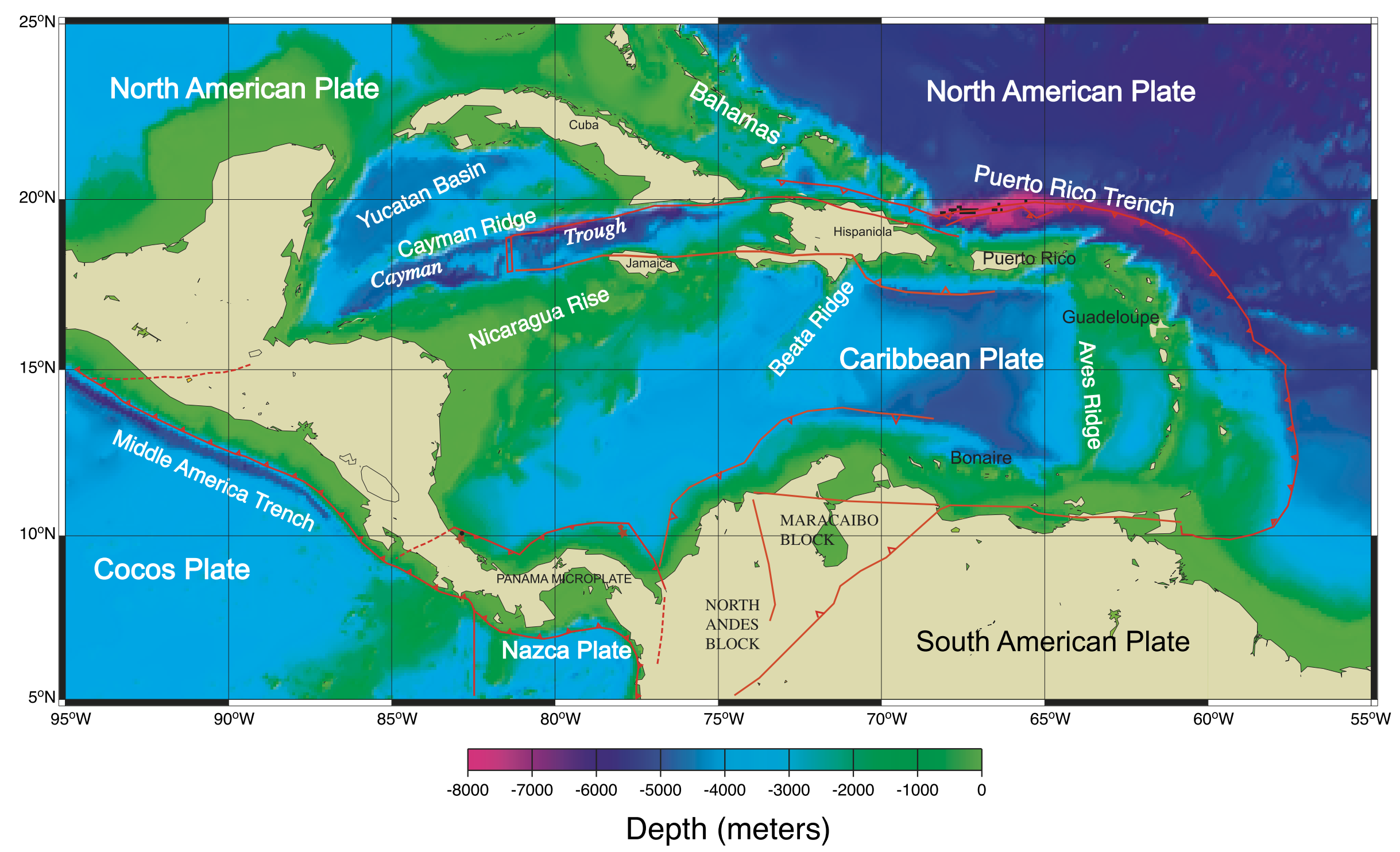

Figure 1. The Caribbean region showing locations of Puerto Rico, Guadeloupe, and Bonaire relative to the major physiographic elements and tectonic plate boundaries. 


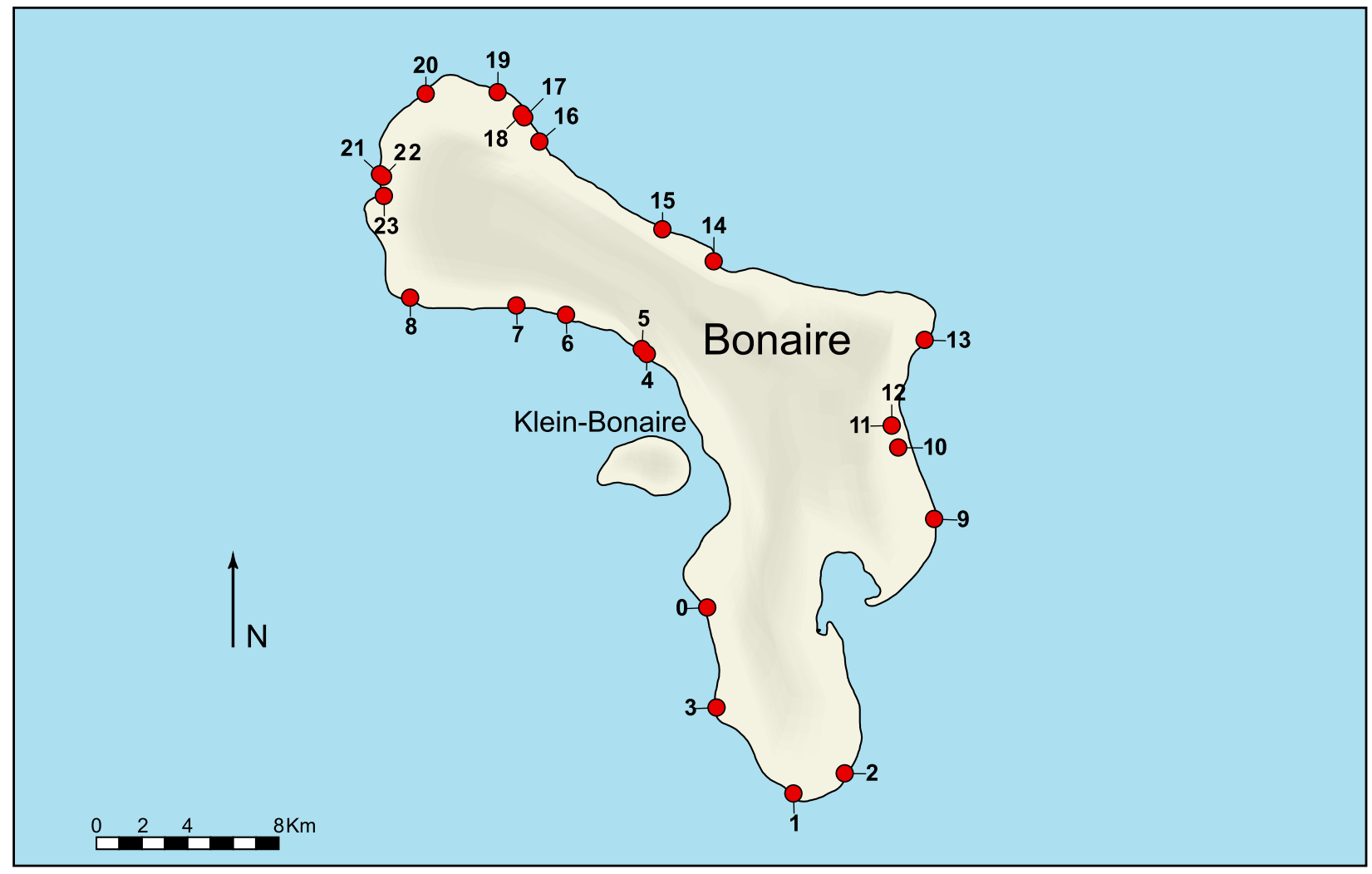

Figure 2. Locations of observation sites in Bonaire.

capable of generating tsunamis, are recurrent events in the region as a result of the North American, South American, and Atlantic plates moving obliquely westward relative to the Caribbean plate. The zone of oblique subduction between the North American and Caribbean plates forms the deep Hispaniola and Puerto Rico trenches, which lie north of the islands of Hispaniola and Puerto Rico, respectively. The deep ocean Mona Passage on the western side of Puerto Rico and associated Mona Canyon are in the zone of transtension created by separation of the Puerto Rico microplate from Hispaniola (McCann, 2006). Rupture of a fault in the Anegada trough was responsible for the 1867 earthquake and tsunami that impacted the Virgin Islands, whereas failure of the Mona Canyon Fault generated the 1918 earthquake and tsunami that inundated northwestern Puerto Rico (Lander and others, 2002).

Most islands of the Caribbean region owe their origins to formation, growth, and emergence of submarine volcanoes. As a result, they typically have a core of volcanic rocks that is surrounded by coral reef limestones and other associated carbonates that were deposited in the shallow, warm tropical sea. Even today there are many active volcanoes along the island arc of the Lesser Antilles between Puerto Rico and Venezuela (Pararas-Carayannis, 2004). Recent major volcanic eruptions that generated local tsunamis (Zahibo and Pelinovsky, 2001; Lander and others, 2002; Pararas-Carayannis, 2004) include the 1995 explosion of Soufriere Hills and 1997 debris avalanche on Montserrat, the 1902 explosion of Mt. Pelée on Martinique, and the 1990 explosion of Kick'em Jenny, an active submarine volcano north of Granada. Flank failures and other landslides around these volcanic islands have produced massive debris flows (Deplus and others, 2001) that likely have generated local tsunamis.

Details of late Quaternary sea-level fluctuations and vertical movement of land masses in the Caribbean region are not well known, and yet that 


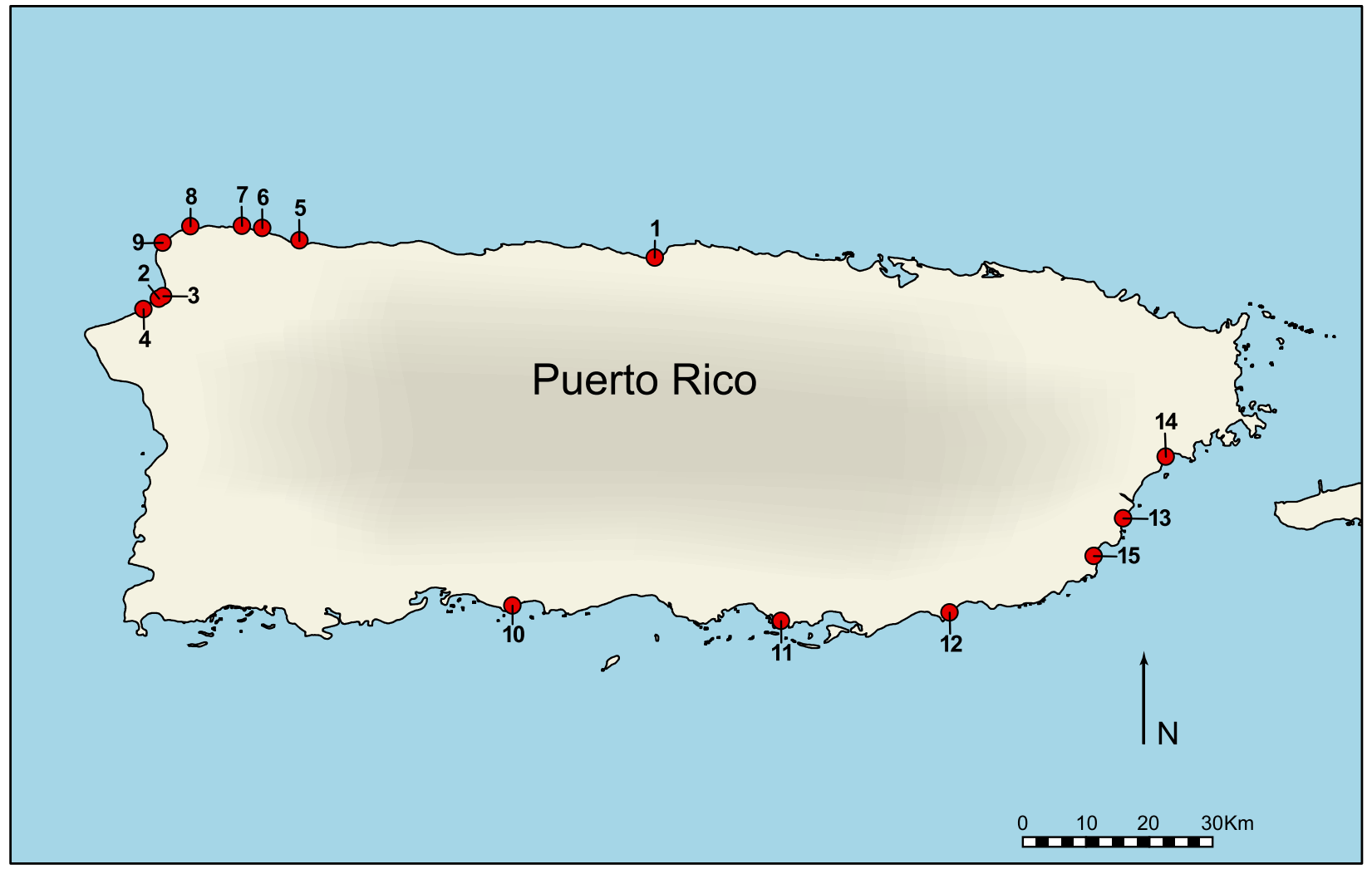

Figure 3. Locations of observation sites in Puerto Rico.

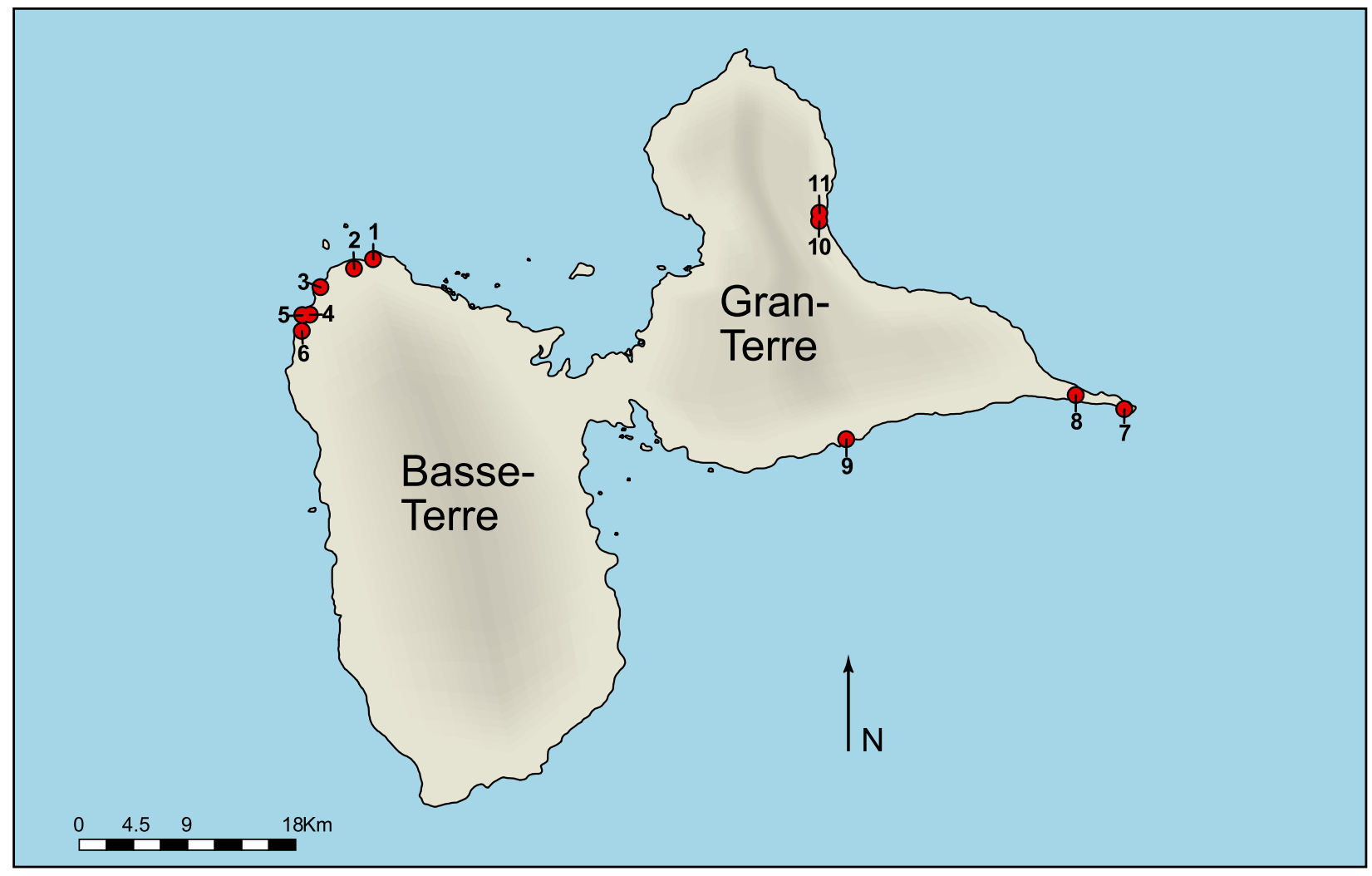

Figure 4. Locations of observation sites in Guadeloupe. 
Table 1. Descriptions and data collected at field observation sites in Bonaire. Data key, $\mathrm{P}=$ photographs, E=mining exposure. Numbered sites shown on Figure 2.

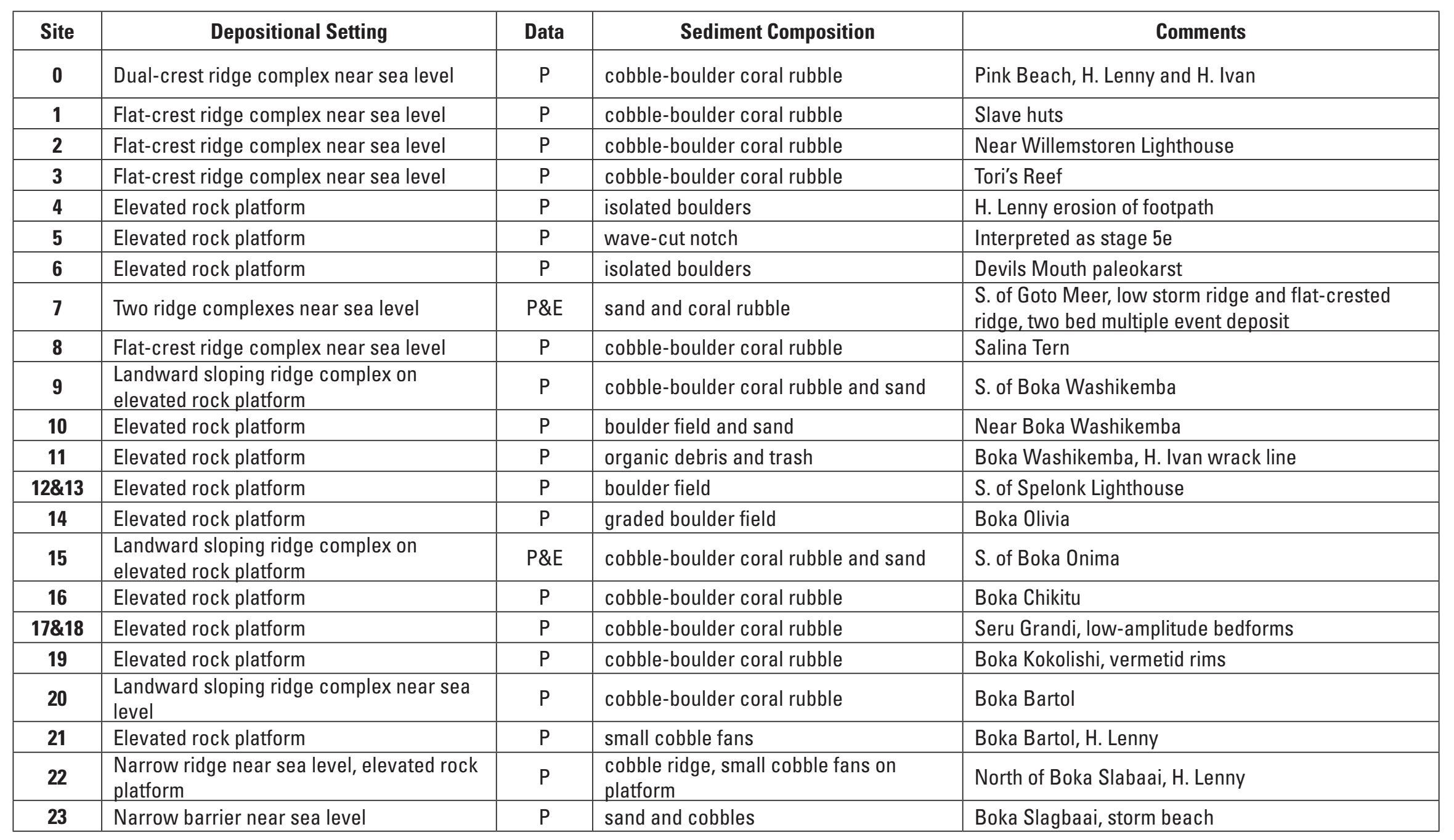


Table 2. Descriptions and data collected at field observation sites in Puerto Rico. Data key, $\mathrm{P}=$ photographs, $\mathrm{C}=\mathrm{core}, \mathrm{T}=$ trench\#, $\mathrm{S}=\#$ of samples, E=exposure. Numbered sites shown on Figure 3.

\begin{tabular}{|c|c|c|c|c|}
\hline Site & Depositional Setting & Data & Sediment Composition & Comments \\
\hline 1 & Coastal plain and wetland & $\mathrm{P}, \mathrm{C} 1-2, \mathrm{~S} 2$ & dark brn. sandy peat, brn. muddy sand, brown mud & Laguna Tortuguero wetland core \\
\hline 2 & Coastal plain and wetland & $\mathrm{P}, \mathrm{C} 3, \mathrm{~T} 1-3, \mathrm{~S} 12$ & dark gray mud with organics and roots & $\begin{array}{l}\text { Espinar, some fill, wetland core, } \\
\text { recent overwash }\end{array}$ \\
\hline 3 & Coastal plain and wetland & $\mathrm{P}, \mathrm{C} 4-5$ & brn. and gray sandy mud, sand with heavy min. layer & Parque Aguadilla, wetland core \\
\hline 4 & Coastal plain and wetland & $\mathrm{P}, \mathrm{C6}-7, \mathrm{~T} 4$ & $\begin{array}{l}\text { dark. brn. sandy peat, tan muddy sand and sand with shell, } \\
\text { upward fining }\end{array}$ & Aguada Beach, wetland core \\
\hline 5 & Coastal plain and wetland & $\mathrm{P}, \mathrm{C}-8, \mathrm{~T} 5-7$ & dark brn. muddy sand mottled gray, stiff mud & $\begin{array}{l}\text { Escuela Epifaunio Estrada, wetland } \\
\text { core }\end{array}$ \\
\hline 6 & Coastal plain and wetland & $\mathrm{P}, \mathrm{Cg}, \mathrm{S} 1$ & gray muddy sand, peat, muddy sand, peat, sand/shell & Isabela Beach, wetland core \\
\hline 7 & Coastal plain and wetland & $\mathrm{P}, \mathrm{C} 10, \mathrm{~T} 8, \mathrm{~S} 4$ & tan and gray sand, lam. mud with 2 thin sand layers/shell & $\begin{array}{l}\text { East Bajura, wetland core, recent } \\
\text { overwash }\end{array}$ \\
\hline 8 & Coastal plain and wetland & P, C11 & dark brn. organic sand, tan sand/coral gravel, gray sand & Maleza Alta, wetland core \\
\hline 9 & Sea cliff and beach & $\mathrm{P}$ & rocky beach, sea cliff, destroyed lighthouse & Point Borinquen 1918 tsunami \\
\hline 10 & Tidal flat and mangroves & $\mathrm{P}, \mathrm{C} 12, \mathrm{~S} 1$ & $\begin{array}{l}\text { brn. muddy sand grading to gray muddy sand, gray mud with } \\
\text { red/brn. organics and muddy peat }\end{array}$ & Punta Cucharas, tidal-flat core \\
\hline 11 & Tidal flat & $\mathrm{P}, \mathrm{C} 13$ & $\begin{array}{l}\text { brn. organic mud, gray mud, brn. mud, gray sand, coarse white } \\
\text { carbonate sand }\end{array}$ & Punta Arenas, tidal-flat core \\
\hline 12 & Coastal plain and wetland & $\mathrm{P}$ & no observations & Punta Figuras, beach ridges \\
\hline 13 & Coastal plain and wetland & $\mathrm{P}, \mathrm{C} 14-15, \mathrm{~S} 7$ & drk. brn. peat and muddy peat, coarse sand /organics & $\begin{array}{l}\text { Palmas del Mar, wetland cores, some } \\
\text { fill }\end{array}$ \\
\hline 14 & Coastal plain and wetland & $\mathrm{P}, \mathrm{Tg}$ & $\begin{array}{l}\text { tan mud, gray muddy sand, gray sand, white carbonate sand/ } \\
\text { shell frags }\end{array}$ & Rio Blanco, tree harvesting \\
\hline 15 & Coastal plain & $\mathrm{P}, \mathrm{T} 10, \mathrm{E}, \mathrm{S} 1$ & multiple sand layers containing rope, plastic, alum. cans & Bella Lucia, recent overwash \\
\hline
\end{tabular}


Table 3. Descriptions and data collected at field observation sites in Guadeloupe. Data key, $\mathrm{P}=$ photographs, $\mathrm{C}=$ core\#, $\mathrm{S}=\#$ of samples, E=mining exposure. Numbered sites shown on Figure 4.

\begin{tabular}{|c|l|l|l|l|}
\hline Site & \multicolumn{1}{|c|}{ Depositional Setting } & \multicolumn{1}{|c|}{ Data } & \multicolumn{1}{|c|}{ Sediment Composition } & \multicolumn{1}{c|}{ Comments } \\
\hline $\mathbf{1}$ & Coastal plain and pond & P, E S2 & sand and cobble/boulders & Point Allegre, recent overwash \\
\hline $\mathbf{2}$ & Coastal plain and wetland & P, S1 & sand & Plage de Cluny, ridge with high avalanche slope \\
\hline $\mathbf{3}$ & Coastal plain and wetland & P, C1 S2 & tan and gray root-mottled mud & Plage de la Perle, mangrove wetland \\
\hline $\mathbf{4}$ & Coastal plain and lagoon & P & no observations & Grand Anse lagoon \\
\hline $\mathbf{5}$ & Coastal plain and wetland & P & sand and slightly muddy sand & Grand Anse park, low beach ridges \\
\hline $\mathbf{6}$ & Beach and steep slope & P & covered by development & Deshaise, church hit by 1867 tsunami \\
\hline $\mathbf{7}$ & Cliffs and coastal plain & P & boulders on beach and rock platform & Pointe des Chateaux \\
\hline $\mathbf{8}$ & Beach & P & beach rock and sand & Anse Tarare \\
\hline $\mathbf{9}$ & Narrow coastal plain & P & covered by development & St. Anne, church hit by 1755 tsunami \\
\hline $\mathbf{1 0}$ & Narrow coastal plain & P, E & mixed sand and cobbles, isolated boulders & Anse Ste. Marguerite \\
\hline $\mathbf{1 1}$ & Narrow coastal plain & P & mixed sand and cobbles, isolated boulders & Anse Maurice \\
\hline
\end{tabular}


history of relative sea-level changes is critical to understanding the origins of elevated coastal deposits on some of the islands. The relative vertical motion of land and sea involves independent tectonic processes (subsidence, uplift) and glacio-eustatic sea level fluctuations along with subsequent balancing of ocean water levels and crustal deformation, known as glacial isostatic adjustment (GIA). The GIA model results explain the documented monotonic rise in Holocene sea level and absence of a midHolocene highstand in the Caribbean region as the result of balancing between the glacial meltwater component and the equatorial ocean siphoning component. The latter component being the principal effect in those regions where water flowed away from far-field regions toward the collapsed forebulge regions to fill the accommodation space created by subsidence of the sea floor (Mitrovica and Milne, 2002). After values for lithospheric thickness and viscosity of different regions were adjusted, results of the GIA model runs match favorably the postglacial sea level curves from the east coast of South America and from the Caribbean, which include curves from Jamaica and Curacao (Milne and others, 2005). The model data for Curacao, in the southern Caribbean Sea, suggest there was no Holocene sealevel highstand for the island.

\section{EXTREME WAVE EVENTS AND DEPOSITS IN THE CARIBBEAN SEA - A BRIEF OVERVIEW}

Coastal flooding hazards in the Caribbean region are caused primarily by extreme ocean waves, which can be generated by either tropical cyclones (storms) or tsunamis. These extreme wave events inundate low-lying coastal areas with salt water, erode beaches, and transport sediments inland where they can be preserved as a record of the event. Extreme wave events in the Caribbean also are responsible for entraining, transporting, and depositing coarse clasts, including megaclasts, which have been reported on many islands (Jones and Hunter, 1992;
Taggart and others, 1993; Hearty, 1997; Scheffers, 2002, 2004; Scheffers and others, 2005, Scheffers, 2005; Scheffers and Kelletat, 2006; Robinson and others, 2006). Following are summaries of the general conditions that generate extreme waves in the Caribbean Sea, the most recent significant storm and tsunami events that affected the islands of Bonaire, Puerto Rico, and Guadeloupe, and previously reported storm and tsunami deposits in the Caribbean region.

\section{Historical Hurricanes}

Tropical cyclones (tropical storms and hurricanes) are annual events that generate extreme waves in the Caribbean Sea. Each year there are at least 10 to 12 named hurricanes and tropical storms active in the Atlantic Ocean, Caribbean Sea, or Gulf of Mexico. That means each year several tropical cyclones impact the shores of at least a few Caribbean islands. Many hurricanes entering the Caribbean Sea originate as classical Cape Verde tropical systems in the Atlantic Ocean off the northwest coast of Africa north of the equator (Fig. 5). These intense storms, which track from east to west, exhibit counter-clockwise wind circulation around a center of low barometric pressure (Simpson and Riel, 1981).

As a result of storm movement and associated wind patterns, east- and north-facing shores typically experience the greatest impacts from high storm surge and wind-driven currents. South facing shores are impacted when the storms track south of the islands. Extremely rare exceptions to these paths and impact patterns are caused by storms that form within the region that track from west to east, such as Hurricane Lenny in 1999. Because the zone of cyclogenesis is centered roughly $10^{\circ}$ north of the equator, frequency of impacts from hurricane-generated waves is highest in the northern Caribbean (Puerto Rico, Haiti, Dominican Republic, Cuba, Jamaica), and decreases toward the southern Caribbean (islands of the Netherlands Antilles and the north coast of South America). 


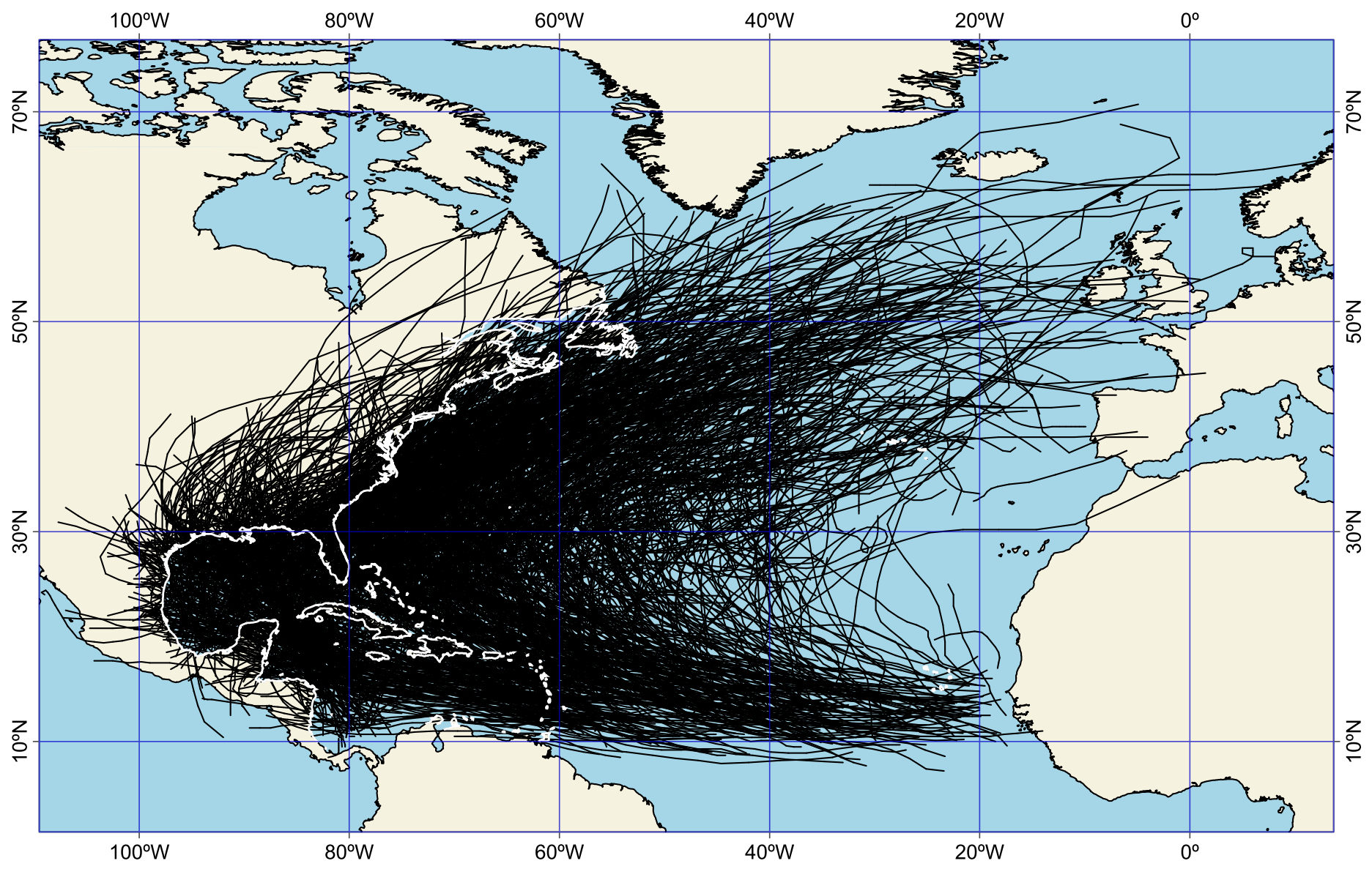

Figure 5. Tracks of all Atlantic tropical cyclones between 1851 and 2005. Obtained from the National Hurricane Center (http://www.nhc. noaa.gov/index.shtml).

Hurricane winds generate and propagate deep ocean swell that can cause substantial coastal change far from the storm center. This principle of coastal change caused by breaking waves from distant storm sources was well documented by sandy overwash deposits observed by one of us (RAM) in a village on Tierrabomba, an island south of Cartagena, Colombia. Flooding from Hurricane Lenny, which was centered more than $500 \mathrm{~km}$ north of the Caribbean coast, caused the overwash. The principle of distant swell and coastal change is also important for Bonaire. A query of the NOAA (2006) historical tropical cyclone database shows that since 1851, no category 3-5 hurricanes have come within $100 \mathrm{~km}$ of Bonaire and only 11 tropical storms or hurricanes of category 1 and 2 have crossed or passed that close to the island. In contrast, Hurricanes Ivan
(2004) and Lenny (1999), both category 4 storms (Saffir-Simpson scale) came no closer than 110 $\mathrm{km}$ and $375 \mathrm{~km}$ respectively from Bonaire, and yet their waves constructed or reshaped coral rubble ridges near sea level and moved megaclasts on rock platforms (Scheffers, 2005). The historical data demonstrate that storm waves frequently impact the shores of Bonaire either as a result of less intense storms passing close to the island or the effects of deep-ocean swell generated by high intensity storms passing farther from the island.

In Puerto Rico, beaches and adjacent coastal plains are regularly flooded by high-energy storm waves. Since 1867 there have been 14 category 3 or 4 hurricanes that have crossed or come within $75 \mathrm{~km}$ of Puerto Rico. The most recent category 4 events to cause widespread beach erosion and overwash 
were Hurricanes Hugo (1989) and Georges (1998). Like Puerto Rico, Guadeloupe lies within the paths taken by many tropical cyclones. As a result, there have been 11 category 3 or category 4 hurricanes that have crossed or come within $75 \mathrm{~km}$ of the island since 1871 (NOAA, 2006). Five of those storms (unnamed, 1899; unnamed, 1926; Cleo, 1964; Inez, 1966; and Hugo, 1989) passed directly over either Grande-Terre or Basse-Terre. There are also accounts of older extreme storms striking Guadeloupe, such as the 1776 event that killed more than 6000 people (Depradine, 1989). The most recent intense storms to impact the east coast of Guadeloupe were Georges (1998), Luis (1995,), and Hugo (1989). The eye wall of Hugo crossed the island at Anse Ste. Marguerite with wind speeds of $220 \mathrm{~km} / \mathrm{hr}$.

\section{Historical Tsunamis}

All the most common mechanisms for generating local tsunamis (earthquakes, landslides, volcanic eruptions) are present in the Caribbean Sea. Caribbean island shores facing east toward the Atlantic Ocean also are at greatest risk from transoceanic tsunamis generated by remote sources, such as the one caused by the Lisbon, Portugal earthquake in 1755. Lander and others (2002) reviewed a 508-year record of written accounts of 91 anomalous wave events in the Caribbean region between 1492 and 2000. Based on their analyses they were able to verify 27 historical tsunamis and concluded that an additional nine events were likely tsunamis. The remaining $60 \%$ of the reported wave events were attributed to other ocean phenomena such as hurricane storm surges, or rogue waves.

Nearly all islands within the Caribbean region have experienced an historical tsunami. However, tsunamis generated in the Caribbean Sea tend to be highly focused so their impacts are limited to short segments of only one or a few islands. Their local runup elevations can be high, but they do not have the global impact of teletsunamis, such as the 2004 Indian Ocean event.
Of the historical tsunamis that impacted Puerto Rico in 1867, 1918, and 1943 (Lander and others, 2002), the 1918 event was the most devastating. This event with a reported maximum wave height of $6 \mathrm{~m}$ (Reid and Taber, 1919) inundated the northwest coast of the island where its greatest effects were felt between the coastal communities of Bajura and Aguada (Moya and Mercado, 2006). Mercado and McCann (1998) modeled the runup from the 1918 tsunami along the west coast of Puerto Rico and obtained results that reasonably matched the observations of eyewitnesses.

According to historical reports, the island of Guadeloupe experienced tsunamis in 1690, 1842, 1867, 1985, and 2004 (Lander and others, 2002; and Zahibo and others, 2005). The latter two events were insignificant because wave heights were substantially less than one meter. The most significant tsunami to strike Guadeloupe, which was in 1867, had a reported wave height of $18.3 \mathrm{~m}$ (Lander and others, 2002), but subsequent modeling and reinterpretation of eyewitness reports indicates wave runup was probably less than $10 \mathrm{~m}$ (Zahibo and Pelinovsky, 2001).

No historical tsunamis have been reported on Bonaire but that does not mean that the island is exempt from tsunami hazards considering its tectonic setting near the northern coast of Venezuela, which is an earthquake-generating region. Many tsunamis associated with earthquakes have locally inundated the northern coast of Venezuela including some of the oldest reported tsunamis for the southern Caribbean Sea. The catalog of tsunami events and analysis of local tsunami impacts on the Caribbean coast of Venezuela (Lander and others, 2002; Schubert, 1994) provide a basis for evaluating tsunami risks on Bonaire.

\section{Reported Tsunami and Storm Deposits in the Caribbean Region}

Despite the large number of historical storm and tsunami impacts recorded for the Caribbean islands, there are relatively few published reports 
containing adequate geological descriptions of the subaerial coastal sediments deposited by these extreme wave events. Megaclast deposits at nearshore sites on the Grand Caymans, Puerto Rico, Bahamas, Aruba, Curacao, Bonaire, Guadeloupe, Barbados, St. Martin, Anguilla, and Jamaica (Jones and Hunter, 1992; Taggart and others, 1993; Hearty, 1997; Scheffers, 2002, 2004; Kelletat and others, 2004; Scheffers, 2005; Scheffers and others, 2005; Scheffers and Kelletat, 2006; Robinson and others, 2006) have captured the most attention because of their extraordinary particle size and the requirement of extremely powerful waves to transport the large boulders. Although some of the authors interpret the megaclast deposits as tsunamigenic in origin (Jones and Hunter, 1992; Scheffers, 2002, 2004; Kelletat and others, 2004; Scheffers, 2005; Scheffers and others, 2005; Scheffers and Kelletat, 2006), they all acknowledge that either large tsunami or storm waves might have been responsible for the preserved boulder fields and unsorted debris ridges.

The scientific focus on boulder fields and coralrubble ridges in the Caribbean region represents a bias in terms of nearshore deposits because sandy beaches are common around most of the islands. For example, sand beaches are so plentiful in Puerto Rico that they have been heavily exploited for construction aggregate to meet the demands for economic expansion in the country. In fact mining beach and dune sand near San Juan and elsewhere increased shoreline erosion and the inland penetration of storm overwash (Capacete, Martín \& Associates, 1978; Rodríguez and others, 1994). Limits of wave inundation associated with winter storms between 1962 and 1968 were mapped along the north shore of Puerto Rico (Fields and Jordan, 1972), but the associated sand overwash deposits were not investigated. Although sand beaches and shorefaces are common in the Caribbean region, only two reports have been identified that address onshore sand deposits emplaced by hurricanes or tsunamis. Both of the articles are for sand deposits in Puerto Rico (Bush, 1991; Moya and Mercado, 2006).

\section{The Tsunami/Storm Wave Dilemma}

Students of coarse clast coastal deposits commonly are challenged by not knowing if tsunamis or storm waves were responsible for the coarse rubble and boulder fields that can be observed at sites around the world (Bourrouilh-Le Jan and Talandier, 1985; Jones and Hunter, 1992; Taggart and others, 1993; Hearty, 1997; Nott, 1997; Noormets and others, 2002; Williams and Hall, 2004; Scheffers and others, 2005; Scheffers, 2005; Scheffers and Kelletat, 2006; Robinson and others, 2006). Extreme waves are capable of dislodging blocks weighing tens to several hundred tons and emplacing those blocks on superjacent intertidal reef flats or rock platforms elevated above sea level.

Many interpretations of coastal megaclast origins have relied heavily on equations published by Nott $(1997,2003)$ to determine if tsunami or hurricane waves are the most likely mechanism for particle entrainment and movement. Results of calculations using the Nott equations always lead to the conclusion that hurricane waves must be approximately four times higher than tsunami waves to transport the same size particle (Nott, 2003). Nott (2003) assumed that the flow velocity in storm waves is sqrt(gh) (eq. 15), while tsunami flow velocity is 2 sqrt(gh) (eq. 14). The wave height required to overturn boulders, the mode of transport assumed by Nott $(1997,2003)$ goes as the velocity squared, which is proportional to the height of storm waves and to $1 / 4$ the height of tsunami waves. As a result of the assumed flow velocity to wave height relation, a storm wave approximately four times the height of a tsunami is required to transport the same boulder (Table 1 in Nott, 2003). Also the Nott equations are formulated assuming that the forces are primarily drag and the mode of transport is by particle overturning. The assumption of particle overturning may not be correct because there is growing evidence from high wave energy coasts that megaclast movement, at least on rock platforms, is by sliding rather than by overturning (Williams and 
Hall, 2004; Noormets and others, 2004) when the blocks are not fully submerged.

Andrew Moore (2006, personal communication) examined the Nott (1997) equations for particle overturning and underscored their limitations because they don't include inertial forces that likely are important and they incorporate components of other wave equations that may have been misapplied. Moore also pointed out that the Nott equations use the term flow velocity to represent wave celerity and two different types of flow velocity (depth-averaged versus depth-value) as if they all were the same parameter.

Noormets and others (2004) calculated pressures and entrainment values for ocean swell (storms) and turbulent bore (tsunami) conditions and concluded both are capable of quarrying megaclasts from cliff edges given sufficient prior fracturing. They also concluded that shorter period storm waves have higher quarrying capacity and storm surge flooding of the rock platform promotes block transport, but longer period tsunami waves have higher transporting capacities because each wave transports the block for a longer time than a storm wave.

\section{SUMMARY OF SITE OBSERVATIONS}

Coastal deposits on the Caribbean islands can be composed of sand, mixed sand and gravel, or extremely coarse clasts including boulders $(0.25$ $-4.1 \mathrm{~m})$ and blocks $(4.1-65.5 \mathrm{~m})$ as defined by Blair and McPherson (1999). On some islands, such as Puerto Rico, the fringing coastal deposits consist predominantly of sand whereas on other islands, such as Guadeloupe and Bonaire, coastal deposits consist of bimodal sizes including sand mixed with cobble/boulder sized coral rubble derived from adjacent reefs and megaclasts quarried by waves from rock platforms and sea cliffs.

The following discussion summarizes field observations made in March 2006 on the three islands on the basis of common depositional settings that influence the morphologies of the deposits and their origins. Summaries of the site observations are presented in Tables 1-3.

\section{Ridges and Ridge Complexes}

On many Caribbean islands the coastal deposits near the shore are composed of coarse coral reef rubble molded into two different morphologies, ridges and ridge complexes. A ridge is a narrow, wall-like feature up to a few meters high consisting of unconsolidated gravel, shingle, or coral rubble deposited by waves near the shore. This is also the definition of a rampart (Bates and Jackson, 1987), a less commonly used geomorphic term. At time scales of years to decades, ridges are typically unstable landforms that are subsequently reworked by moderate energy waves that cause them to either migrate landward or to be transformed into sheets (Blumenstock and others, 1961; Stoddart, 1965; Baines and McLean, 1976). In the literature the terms gravel ridge (McKee, 1959), storm beach (Baines and others, 1974), storm ridge (Scoffin, 1993), and rampart (Maragos and others, 1973; Baines and McLean, 1976) have been applied to some single-event ridge-like deposits. For this report the term ridge is restricted to an isolated, narrow, low, shore-parallel feature that was deposited initially during a single episode but may subsequently be modified by a few multiple-wave events while still retaining its individual identity.

A ridge complex is a broad, composite, shoreparallel feature generally $>2 \mathrm{~m}$ thick consisting of unconsolidated gravel, shingle, or coral rubble deposited by waves near the shore. A ridge complex can exhibit ridge and swale topography, be flatcrested, or be wedge-shaped generally with the highest crest elevation near the ocean and surface elevations decreasing landward. A ridge complex represents an accumulation of many depositional events resulting from the long-term reworking and coalescence of multiple event deposits including former isolated ridges. At time scales of years to decades, ridge complexes are generally stable landforms that aggrade or prograde seaward as 
additional material accumulates on the seaward side. Similar morphological features have been referred to in the southern Caribbean Sea as ridges (Schubert and Valastro, 1976) and in the Pacific as hurricane banks (Baines and others, 1974), shore ridges (McKee, 1959), ridge-swale complexes (McLean and Hosking, 1991), and beach ridges (Scoffin, 1993). Along paraglacial coasts similar stormdeposited features are referred to as gravel barriers (Orford and others, 2002; Forbes and Syvitski, 1994).

\section{Bonaire}

No historical tsunamis have been reported for Bonaire. Consequently sites investigated around the island for possible tsunami deposits were diverse with respect to their physical settings and to sea level.

\section{Deposits Near the Shore and Near Sea Level}

All the sites visited on Bonaire (Fig. 2) with substantial coarse clasts deposited near the shore and near sea level have many common characteristics (Table 1). One common attribute is their location on the west and south (leeward) sides of the island. These west and south facing shores are generally protected from high-energy waves generated by the predominant trade winds. Deposits near sea level are also common around the southern shores of the island because the landmass has been tilted tectonically so that the southern end has subsided and the northern end uplifted (Alexander, 1961). As a result of this tilting, sea cliffs predominate along the central and northern segments of the island, whereas broad tidal flats prevail along the southern segments. The deposits near sea level generally form ridge complexes a few tens of meters wide that are composed of coral rubble with zones of imbricated clasts concentrated near the shoreline. A narrow barren zone of cemented reef rock or beach rock typically separates the rubble ridge complex from the sea. The ridge complexes have steep concave backbeach slopes that rise to intersect the flat crests (Fig. 6), crest elevations are about 2 to $2.5 \mathrm{~m}$ above sea level (asl), and landward terminations of most of the ridge complexes are steep, well-defined avalanche slopes (Figs. 6 and 7).

A typical example of one of these coarse clast deposits near sea level is north of Willemstoren Lighthouse (Fig. 2, site 2). The ridge complex remnant is composed of a bimodal mixture of sand and coarse clasts with most of the clasts at the surface being cobbles to fine boulders (Fig. 8). A wrack line of wood debris and plastic covers the seaward side of the flat crest, representing evidence of recent storm inundation. Some clasts on the surface and near the shore side of the ridge complex are imbricated. Scheffers (2005) interpreted this 2 to

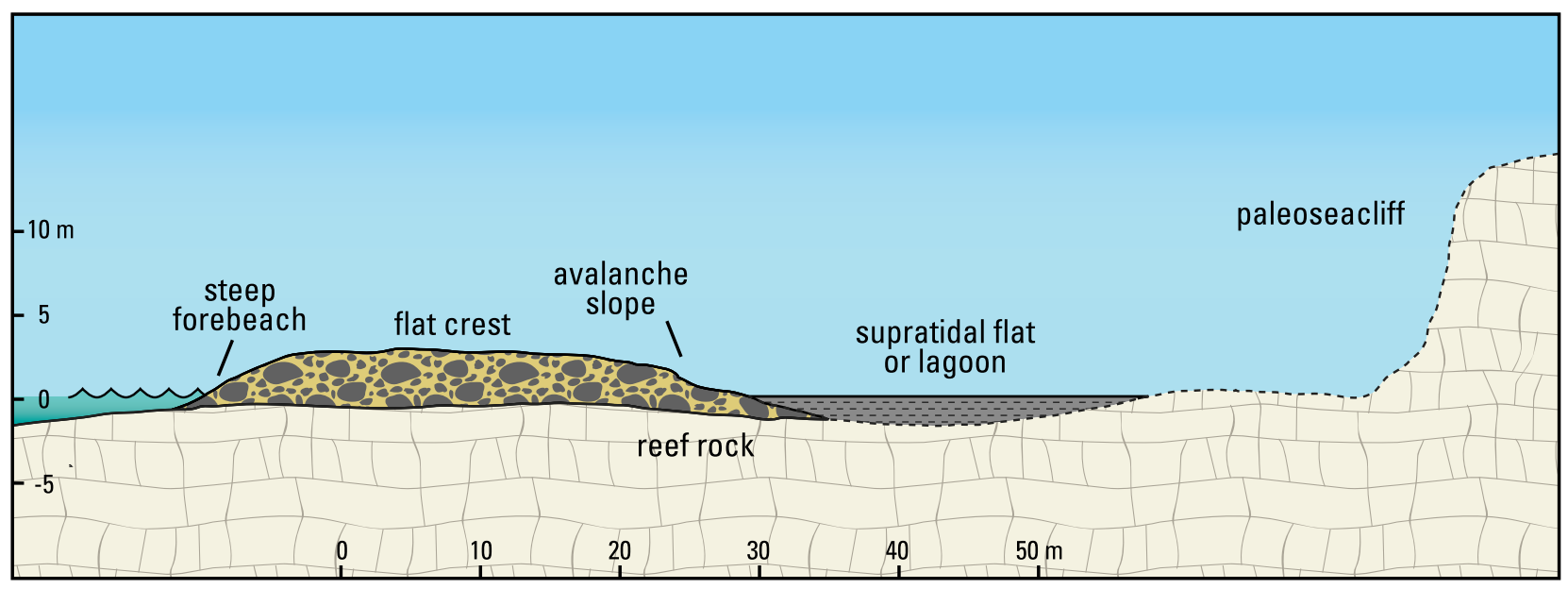

Figure 6. General topographic profile, morphology, and depositional setting of reef-rubble ridge complex near sea level. 


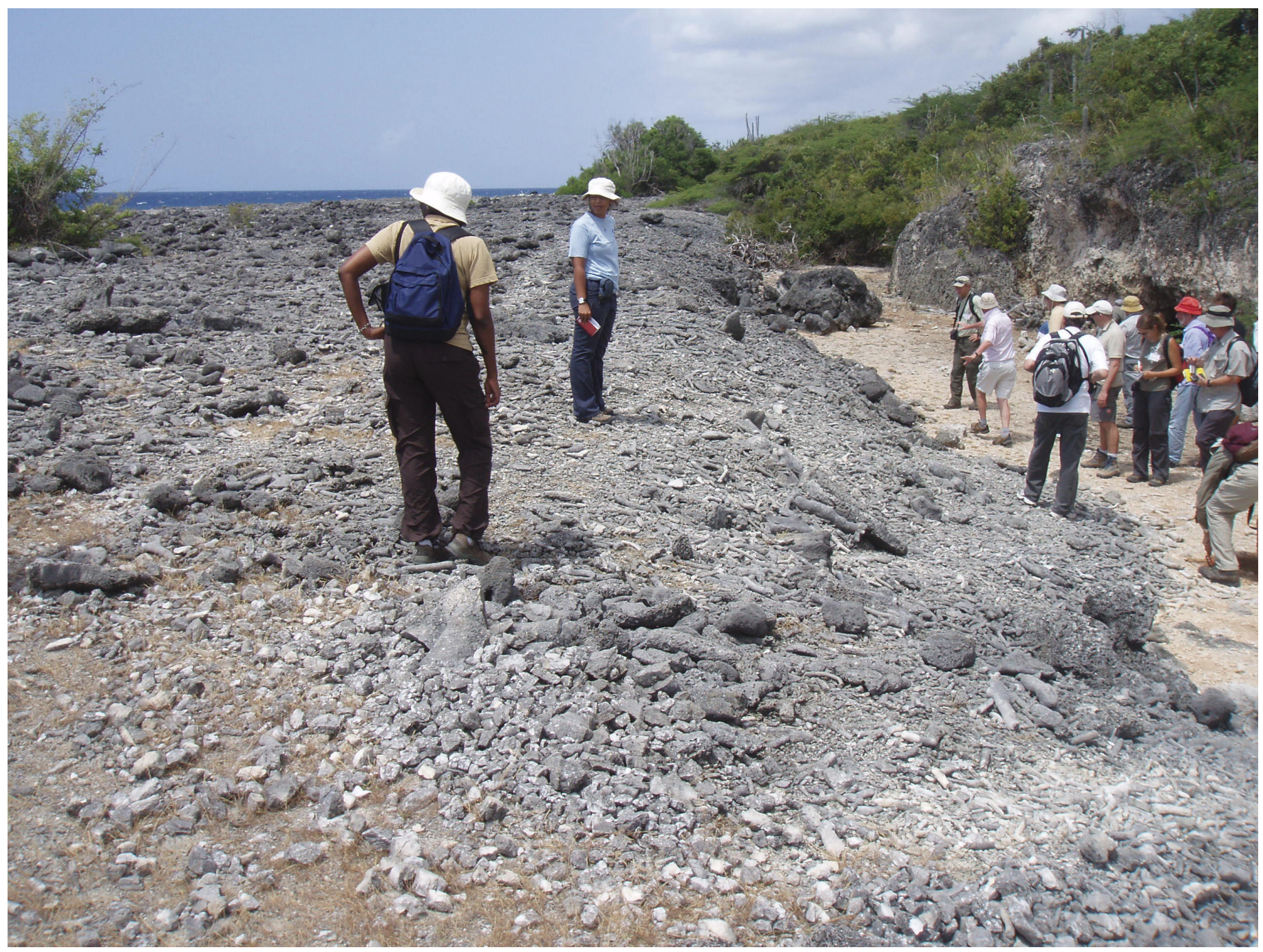

Figure 7. Reef-rubble ridge complex near sea level on the western coast of Bonaire showing flat crest and steep avalanche slope (Fig. 2 , site 8).

$3 \mathrm{~m}$ high, 40-m wide shore-parallel ridge complex as a tsunami deposit. Much of the feature has been removed by extensive mining for construction aggregate. Before mining, a much broader zone of coarse clast accumulation would have formed a ridge complex extending inland at least another $50 \mathrm{~m}$.

North of Boka Slagbaai (Fig. 2, site 22) is a ridge (spit) near sea level composed of cobbles and fine boulders (Fig. 9). Aerial photograph and field evidence (Scheffers, 2005) demonstrate that the ridge was constructed by Hurricane Lenny in 1999 and was modified by Hurricane Ivan in 2004. Comparison of our 2006 photographs with the
post-Ivan photograph of Scheffers (2005) shows subsequent ridge aggradation by smaller, nonhurricane waves that break and run up on the ridge and deposit fine boulders. In 2006 the ridge was about $100 \mathrm{~m}$ long, 5 to $8 \mathrm{~m}$ wide at sea level, and had a narrow, sharp crest that was about $2 \mathrm{~m}$ asl.

At Boka Slagbaai, a low, landward sloping barrier beach near sea level encloses a small wetland-fringed embayment (Fig. 2, site 23). The barrier, which is composed predominantly of sand with some cobbles, was formed by storm overwash that has transported sediments across the barrier and deposited small fans in the adjacent embayment. Fresh sand and pebble-size pieces of coral debris 


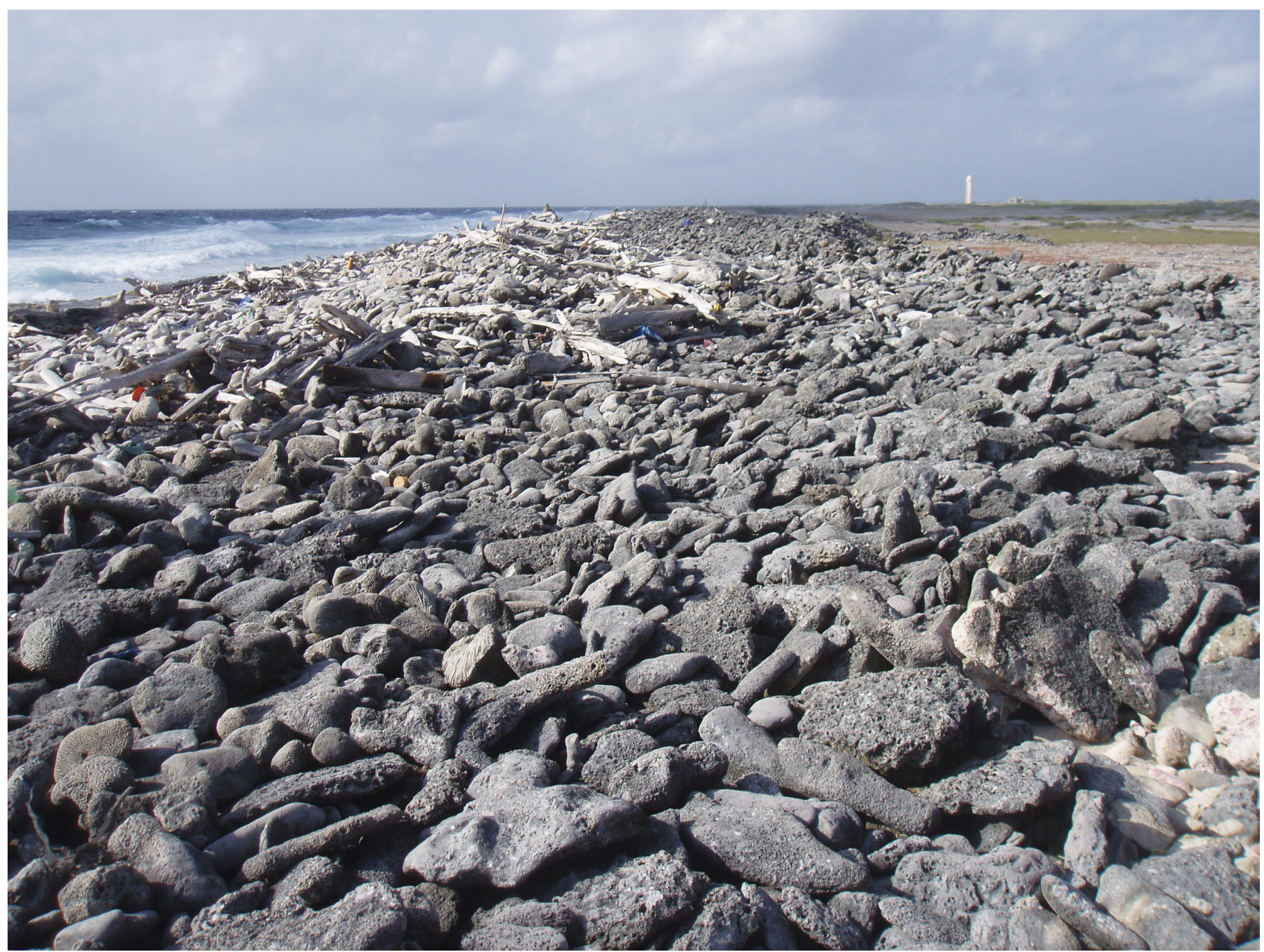

Figure 8. Reef-rubble ridge complex near sea level on the eastern coast of Bonaire showing flat crest, recent storm debris, and clast imbrication (Fig. 2, site 2). Largest clasts in the foreground are approximately $0.5 \mathrm{~m}$ long.

cover the surface of the barrier, which is barren of vegetation. Hurricane Lenny, which was the most recent extreme wave event to overwash the barrier, damaged buildings that were constructed originally in 1868 (Scheffers, 2005).

\section{Elevated Rock Platform Deposits}

Of the 13 sites on Bonaire that have coarse clasts deposited on rock platforms (Table 1) several meters or higher above sea level, eight sites are on the eastern side of the island where exposure to highenergy waves and a limestone terrane results in a near vertical sea cliff. The surfaces of the platforms are covered with microkarst solution cavities. A wave-cut notch near sea level promotes active cliff face retreat that together with joint-controlled fractures make the cliff unstable. Undermining beneath the notch causes blocks to fall into the sea or allows surging waves to more easily quarry blocks by increasing the surface area exposed to uplift and air compression (Noormets and others, 2002).

Coarse clasts deposited on rock platforms above sea level consist mostly of: (1) extensive boulder fields, (2) thick ridge complexes composed of bimodal sediments, (3) small, thin wedge-shaped aprons, or (4) isolated megaclasts. At most of the elevated platform sites (Fig. 2, sites 4, 6, 10, 


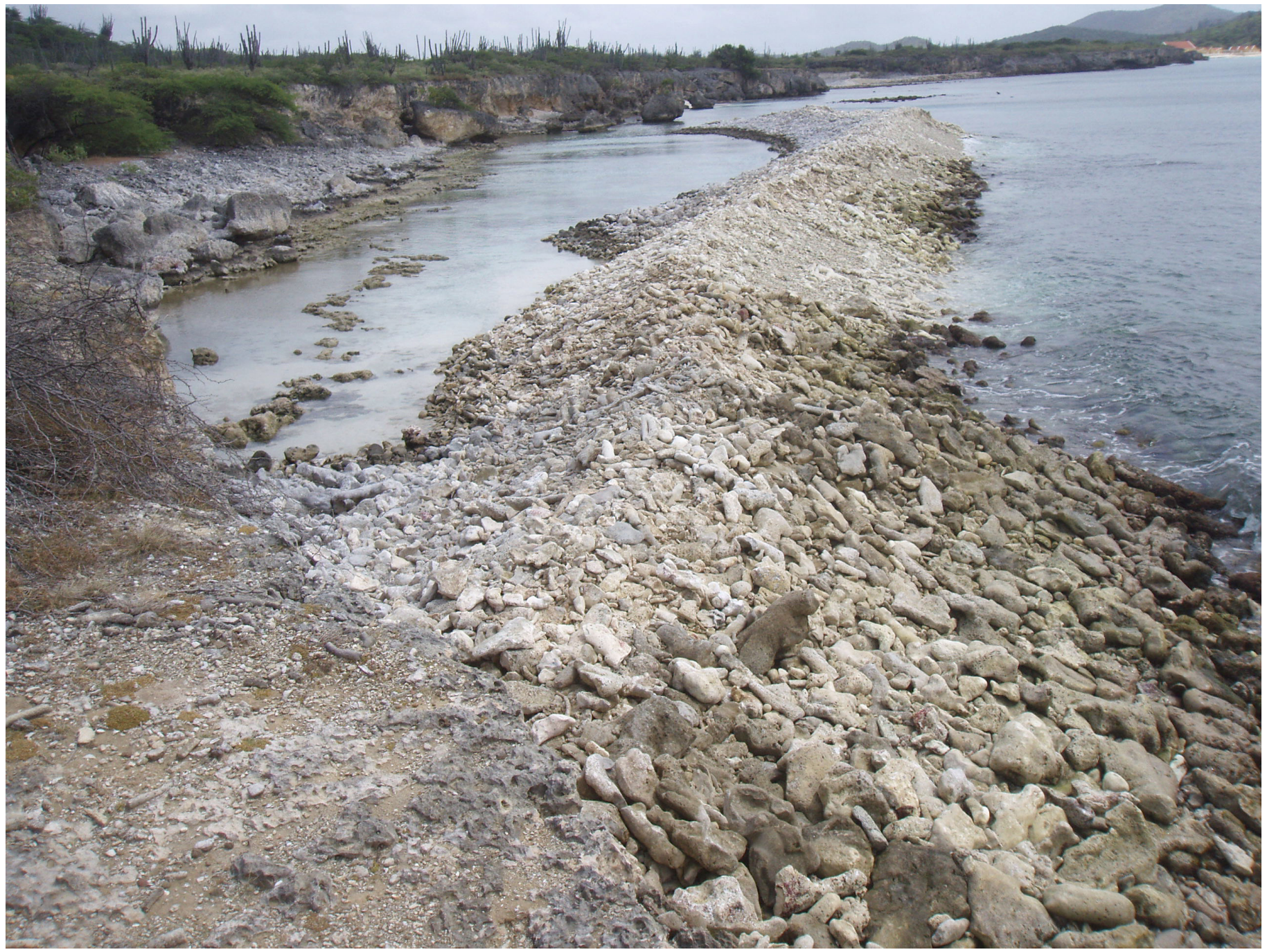

Figure 9. Sharp-crested ridge near sea level on the northwestern coast of Bonaire constructed by Hurricane Lenny and subsequently modified by less energetic waves (Fig. 2, site 22).

\section{$13,14,16,17,19,21,22)$ the deposits are isolated} megaclasts or fields of boulders of various sizes

(Figs. 10-12). At nearly all the sites, the megaclasts are separated from the sea-cliff shoreline by a zone on the platform where loose sediments are absent, having been swept away by repeated storm-wave inundation. On the east side of the island, the rock platform between the present sea cliff and the paleosea cliff is several hundred meters wide. At site 10, blocks having estimated weights of 30 to 50 tons (Scheffers, 2005) are located about $110 \mathrm{~m}$ from the sea cliff where they were quarried by waves and emplaced on the elevated platform about $5 \mathrm{~m}$ asl. The place where boulder field accumulation on the elevated rock platform is most consistent with that expected by a tsunami is site 14 (Fig. 2). There the coarse clasts are graded so that particle size decreases away from the sea-cliff shoreline (Fig. 12). At rock platform sites 4 and 6 on the west coast of the island, the ancestral sea cliff is near the shore and the isolated boulders may have been derived from the ancestral sea cliff and transported down slope to the relatively flat platform by gravity processes.

At sites 9 and 15 (Fig. 2), the coral-rubble deposits form broad landward-sloping ridge complexes composed of bimodal sediments (Figs. 13-16). Mining exposures show that the clast- 


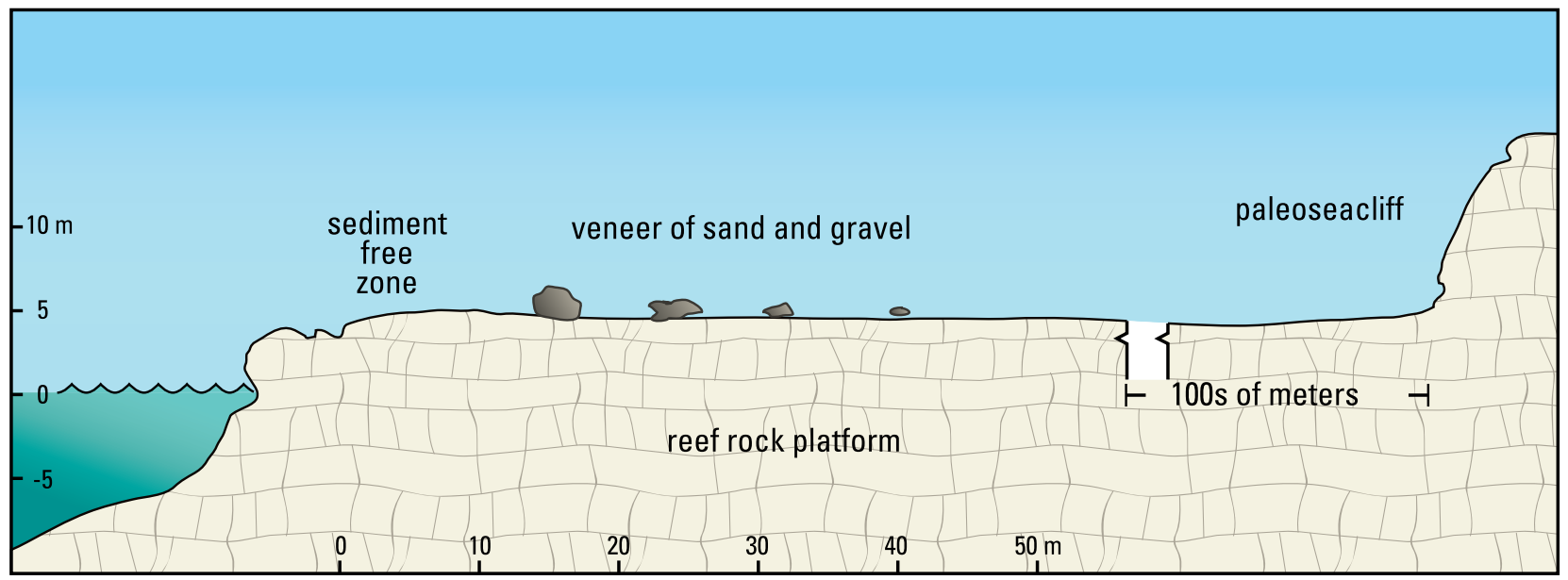

Figure 10. General topographic profile, morphology, and depositional setting of boulder field on elevated rock platform.

supported framework of cobbles and boulders is filled with sand that at the surface is unweathered (Figs. 14-16). This suggests that the bimodal accumulation may be the result of framework deposition by extreme waves and subsequent framework infiltration of sand delivered by less powerful waves. The exposures also show that the sediments are internally organized with crude stratification, vertical textural trends, and bounding surfaces (Figs. 14 and 16). At site 9 (Fig. 2), a shorenormal exposure reveals internally imbricated clasts and steep seaward dipping beds that exhibit upwardfining textural trends (Fig. 14). The dip of the beds is similar to the slope of the ramp face exposed to waves. The juxtaposition of alternating beds of coarse and fine clasts forms crude stratification. At site 15 (Fig. 2), the ridge complex deposits are about $80 \mathrm{~m}$ wide, 3.5 to $4 \mathrm{~m}$ thick at the seaward crest and taper landward forming a wedge. Near its seaward edge the ridge complex consists of two primary stratigraphic units (Fig. 16). The shore-parallel exposure shows that the lower unit is composed of sand and rounded, disc-shaped clasts that exhibit upward-fining textural trends near the top (Fig. 16A). Equant to platy, subrounded to rounded clasts of the overlying upper unit are substantially larger, imbricated, and tend to coarsen upward. The largest clasts are isolated boulders resting on the ridge complex crest (Fig. 16B), which is about $9 \mathrm{~m}$ asl (Scheffers, 2005). The bounding surface separating the two units is a disconformity resulting from distinctly different depositional episodes with different clast sizes deposited. The composition and internal organization of the ridge complex deposits are similar to those illustrated by Bluck (1967) for gravel beaches in south Wales where the framework of coarse clasts is filled with smaller particles including sand, whereas sand is absent from the youngest surficial deposits.

At sites 21 and 22 (Fig. 2) where the rock platform is elevated about $6 \mathrm{~m}$ asl, aprons of rounded light-colored particles that range in size from pebbles to small boulders form a thin wedgeshaped deposit (Fig. 17) that is scalloped along its seaward edge. The small aprons, which thicken landward from individual clasts to a low ridge several clasts thick, also coarsen landward. The aprons, which were deposited by Hurricane Lenny (Scheffers, 2005), are separated from the sea-cliff shoreline by a wave-washed zone of non-deposition.

\section{Puerto Rico}

Most of the potential paleotsunami sites we investigated in Puerto Rico (Fig. 3, Table 2) were in or near reed or mangrove wetlands or on barren tidal flats that are separated from the ocean by a beach and narrow coastal plain composed of sand (Fig. 18). These sites were selected because they represent settings with high preservation potential 


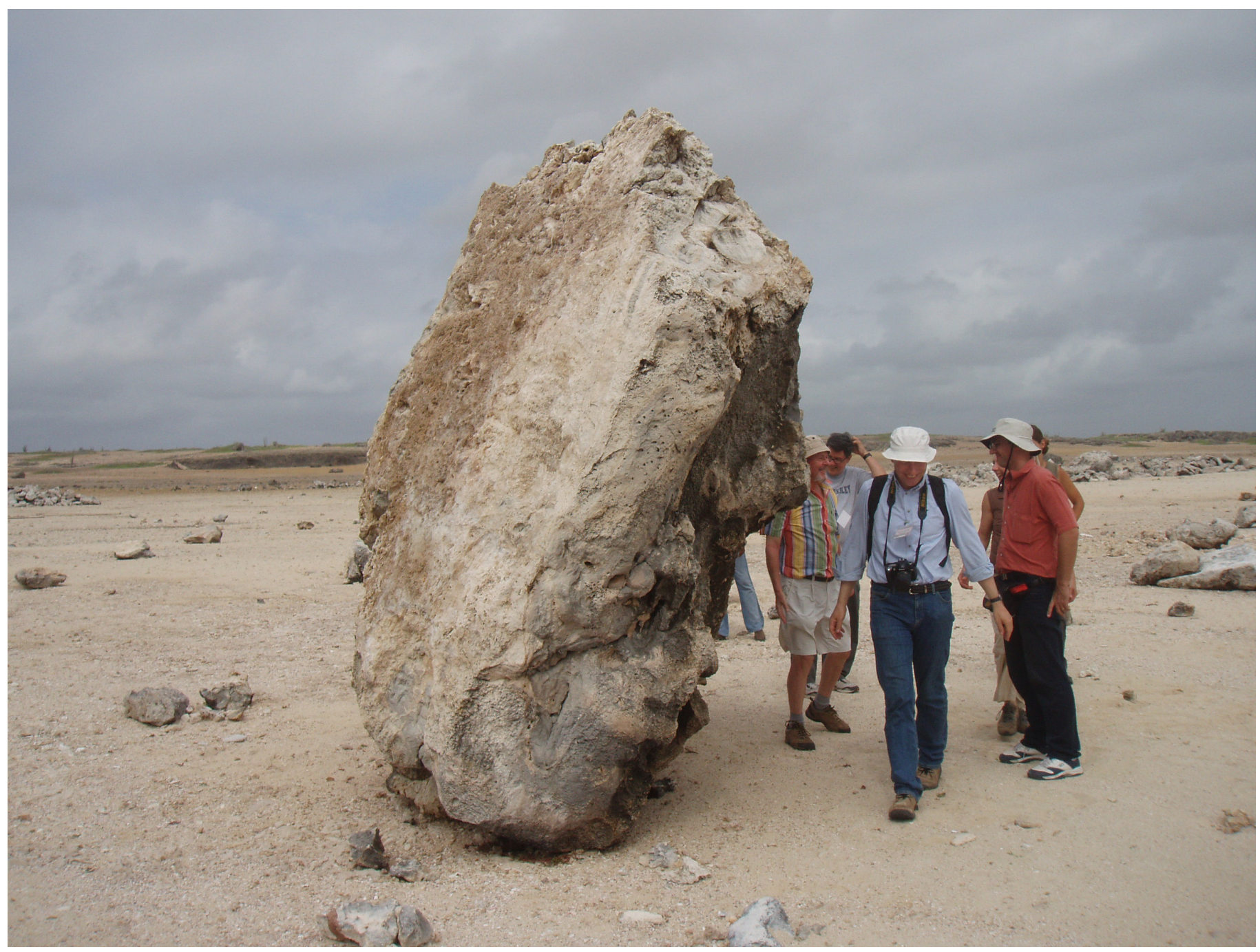

Figure 11. Rock platform on the eastern side of Bonaire. Hurricane Ivan overturned the boulder in 2004 (site 10).

for paleotsunami deposits. During a tsunami event, the beaches and low dunes at the shore would provide a source of sand and the low-energy wetland or tidal flat environments would serve as traps for the high-energy marine sand tsunami deposits. If undisturbed after deposition, the sandy tsunami deposits also would contrast sharply with the peat or muddy wetland or tidal-flat sediments. At several sites (Maleza Alta, Fig. 3, site 8; Punta Arenas, site 11; Palmas del Mar, site 13) coarse gray or white carbonate sand was encountered in the bottom of the cores. These sand deposits may represent openocean platform sediments that were buried when the shoreline advanced seaward during the Holocene coastal regression.
Moya and Mercado (2006) investigated several field sites on the northwest coast of Puerto Rico that according to eyewitnesses were inundated by the 1918 tsunami. They reported finding thin laminated sand deposits with Halimeda sp., shell fragments, or heavy mineral concentrations beneath the wetlands at Espinar (Fig. 3, site 2), Parque Aguadilla (Fig. 3, site 3), and Aguada Beach (Fig. 3, site 4) at depths of 25,39 , and $25 \mathrm{~cm}$ respectively that they interpreted as having been deposited by the 1918 tsunami. The sediment sources or processes that would have deposited the overlying 25 to $39 \mathrm{~cm}$ of sediment in the past 88 years were not evaluated. Moya and Mercado (2006) also reported radiocarbon dates of event deposits of $630 \pm 55 \mathrm{YBP}$ and $2515 \pm 70$ 


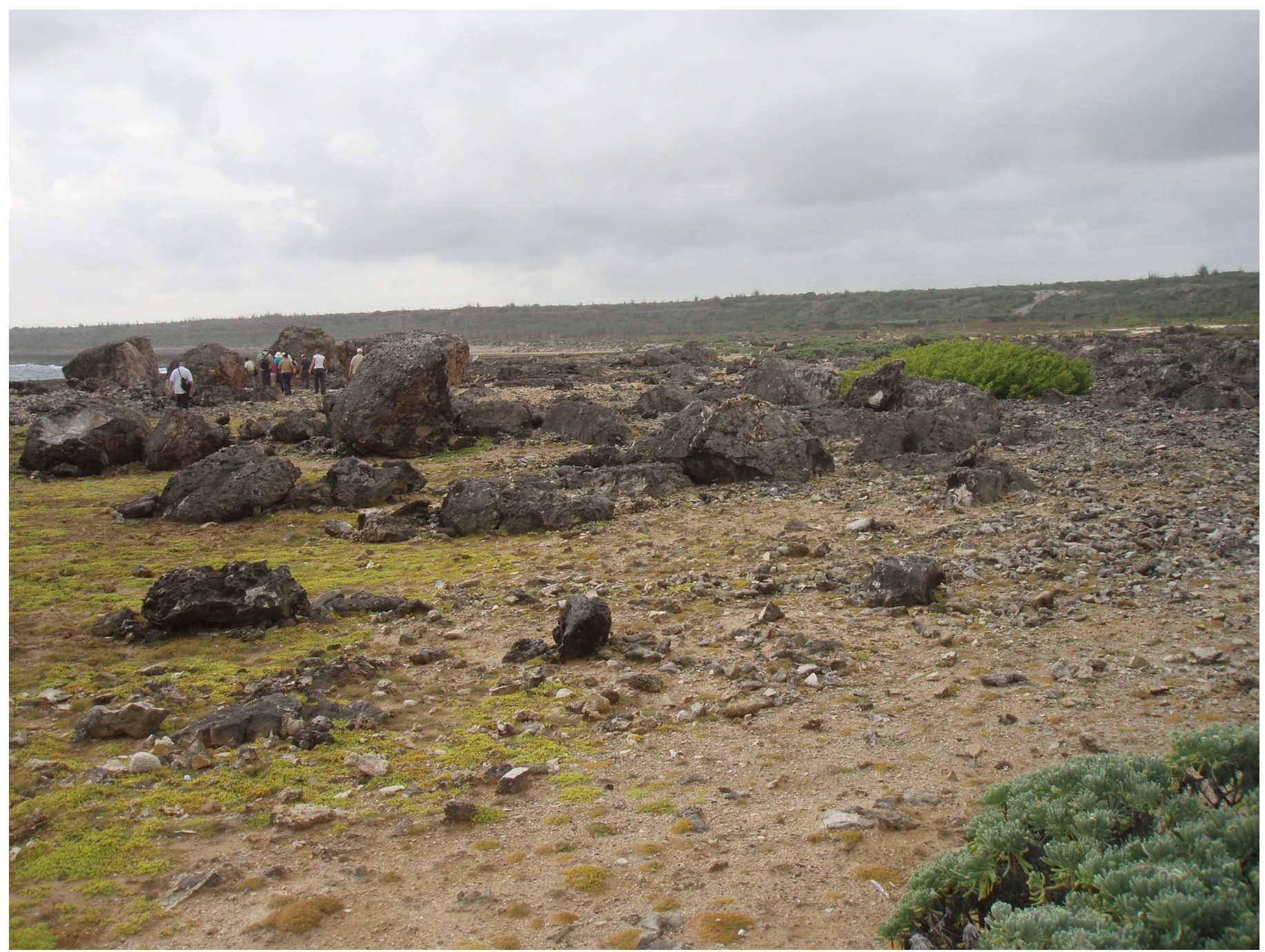

Figure 12. Boulder field on rock platform on the eastern side of Bonaire (Fig. 2, site 14) showing landward decrease in clast size. Oblique view toward the sea.

YBP from a core at Espinar. The sample dated at $630 \pm 55$ YBP is from a depth of about $30 \mathrm{~cm}$, which is comparable to or above the laminated deposits. Considering the characteristics of these thin sand deposits and their contrast with the overlying and underlying sediments it is likely that they are tsunami deposits, but they may be much older than the 1918 event.

\section{Wetland Deposits}

Eleven sites visited in Puerto Rico had typical coastal plain and wetland topographies (Fig. 18, Table 2). A common practice in Puerto Rico, and elsewhere, is filling wetlands to elevate and enlarge potential coastal construction sites. At Espinar and Palmas del Mar (Fig. 3, sites 2 and 13), surface sediments consisted of unsorted gravel, sand, and mud representing fill used to elevate the wetlands. At Parque Aguadilla and Isabela (Fig. 3, sites 3 and 6 ), surface sediment compositions and elevations indicated that former wetlands had been filled and graded, but the cores were taken far enough from the altered surfaces that the cores did not penetrate any of the fill.

On the north coast at East Bajura (Fig. 3, site 7), a high, carbonate-cemented eolianite ridge and narrow coastal plain separate the ocean from a 


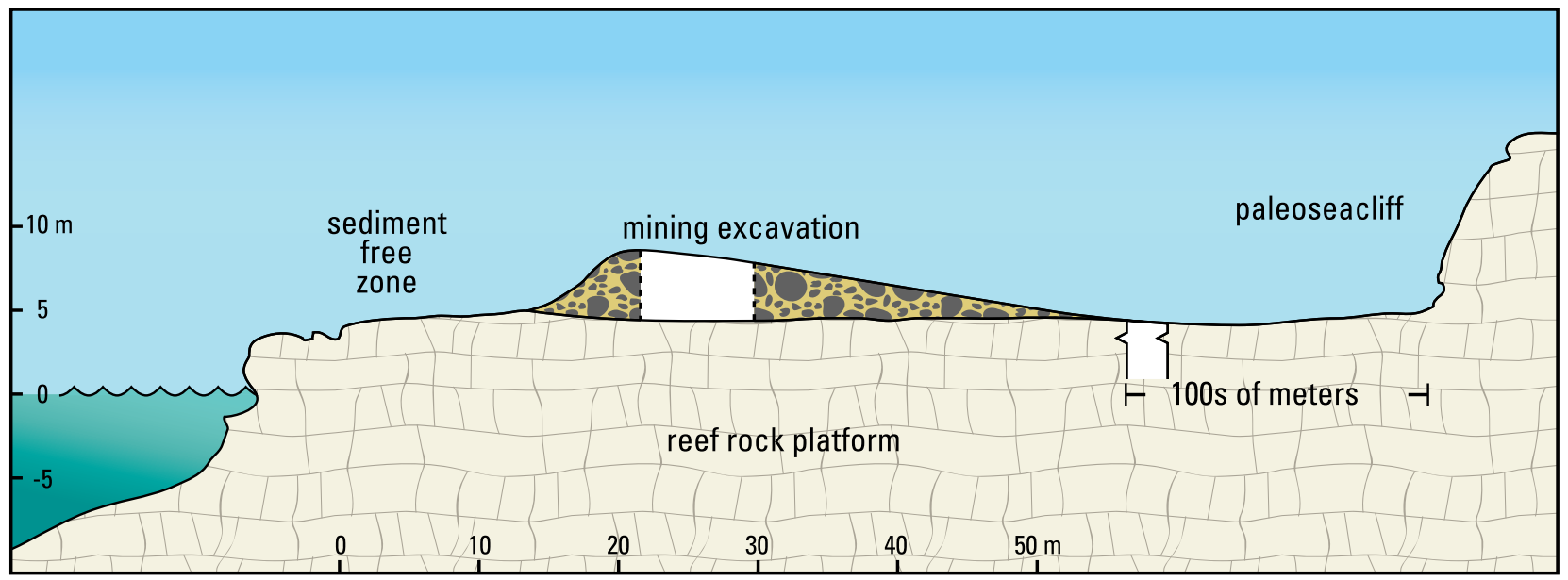

Figure 13. General topographic profile, morphology, and depositional setting of reef-rubble ridge complex on elevated rock platform.

dying mangrove forest. A breach in the eolianite ridge has allowed storm washover to penetrate about $150 \mathrm{~m}$ inland, forming a washover terrace that terminates at the wetland edge in an avalanche face about $1 \mathrm{~m}$ high. Sediments beneath the wetland are composed of about $55 \mathrm{~cm}$ of tan and gray sand over tan laminated mud. Within the mud, at depths of 79 and $86 \mathrm{~cm}$ are two very thin layers of gray sand. The upper layer is capped by whole, unabraided high-spiral gastropods (Fig. 19). Preliminary interpretation of the depositional history of this site is: (1) formation of a coastal lake landward of the eolianite ridge, (2) aggradation of laminated lacustrine muds that was infrequently punctuated by tsunamis that overtopped the ridge and deposited the thin sand layers. (3) Eventually the eolianite ridge was breached and the most recent sand deposition has been a result of (4) frequent storm overwash by high-energy waves focused in the embayment where the ridge was breached. (5) The overwash sufficiently filled the lake and increased the salinity so that a mangrove wetland formed.

Event deposits that could have tsunami origins were identified at two other wetland sites. At Parque Aguadilla on the northwest coast (Fig. 3, site 3), sediments beneath the mangrove wetland are composed of brown and gray sandy mud. Within these mostly muddy sediments, at a depth of 127 to $137 \mathrm{~cm}$, is a layer of gray sand with heavy minerals concentrated at the base. At Palmas del Mar on the southeast coast (Fig. 3, site 13), sediments beneath the wetlands are dark brown peat and muddy peat. At a depth of $224 \mathrm{~cm}$ the composition changes to coarse sand that continues to the bottom of the core at a depth of $241 \mathrm{~cm}$. It is uncertain what type of depositional environment the basal sand represents because the total thickness of the sand and the composition of the sediment below the sand are unknown.

\section{Tidal Flat Deposits}

Sediments beneath tidal flats were investigated at two morphologically similar sites on the south coast of Puerto Rico. Both Punta Cucharas (Fig. 3, site 10) and Punta Arenas (Fig. 3, site 11) are promontories that during the Holocene built into the Caribbean Sea, forming triangular-shaped landforms. The puntas (points) are characterized by beaches and low dunes along their outer margins and by tidal flats and mangrove wetlands that surround shallow interior lagoons. The depositional histories of these features are unknown, but they likely involve fluctuations in sediment supply, wave climate, and possibly sea level.

Sediments beneath a tidal flat at Punta Cucharas are brown and gray muddy sand that grade down into gray mud. Within the mud, at a depth of 99 to $101 \mathrm{~cm}$ is a thin layer of gray sand with shell 


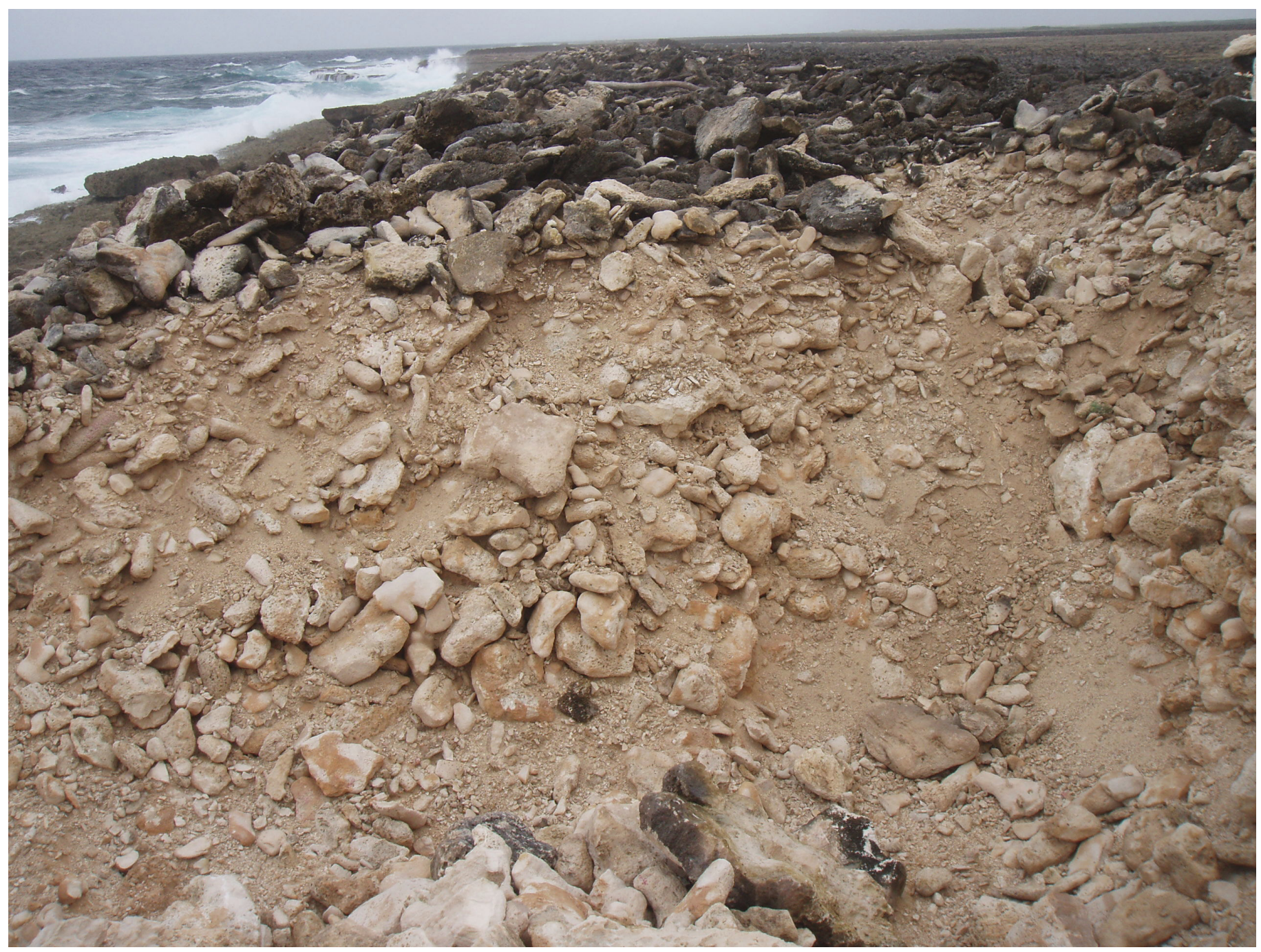

Figure 14. Mining exposure on the eastern side of Bonaire. The exposure, which is on the seaward side of a landward-sloping reef-rubble ridge complex (Fig. 2, site 9), shows seaward dipping, upward fining graded beds. Largest clasts in the foreground are approximately 0.6 $\mathrm{m}$ long.

fragments. The sand and shell layer is an event deposit of unknown origin.

\section{Coastal Plain Deposits}

Only coastal plain sediments were examined at the coconut palm plantation at Bella Lucia (Fig. 3 , site 15). This site appears to be dominated by storm processes and overwash deposition of sand. The evidence of recent beach erosion and frequent storm deposition is exposed in a one-meter-high erosional wave-cut scarp at the shore where multiple sand layers of varying textures are superimposed.
Distributed throughout these sand deposits are strands of plastic rope, pieces of styrofoam, aluminum cans, and other trash at elevations from the surface to the base of the scarp near the lowtide water level. A trench, which was opened about $75 \mathrm{~m}$ inland from the shore, showed homogeneous tan sand with abundant roots. Considering the low elevations and wave exposure of this site and the track of Hurricane Hugo (1989), at least one of the sand layers must be the Hugo deposit, but we were unable to distinguish it from other overwash deposits. Bush (1991) reported that the Hurricane 


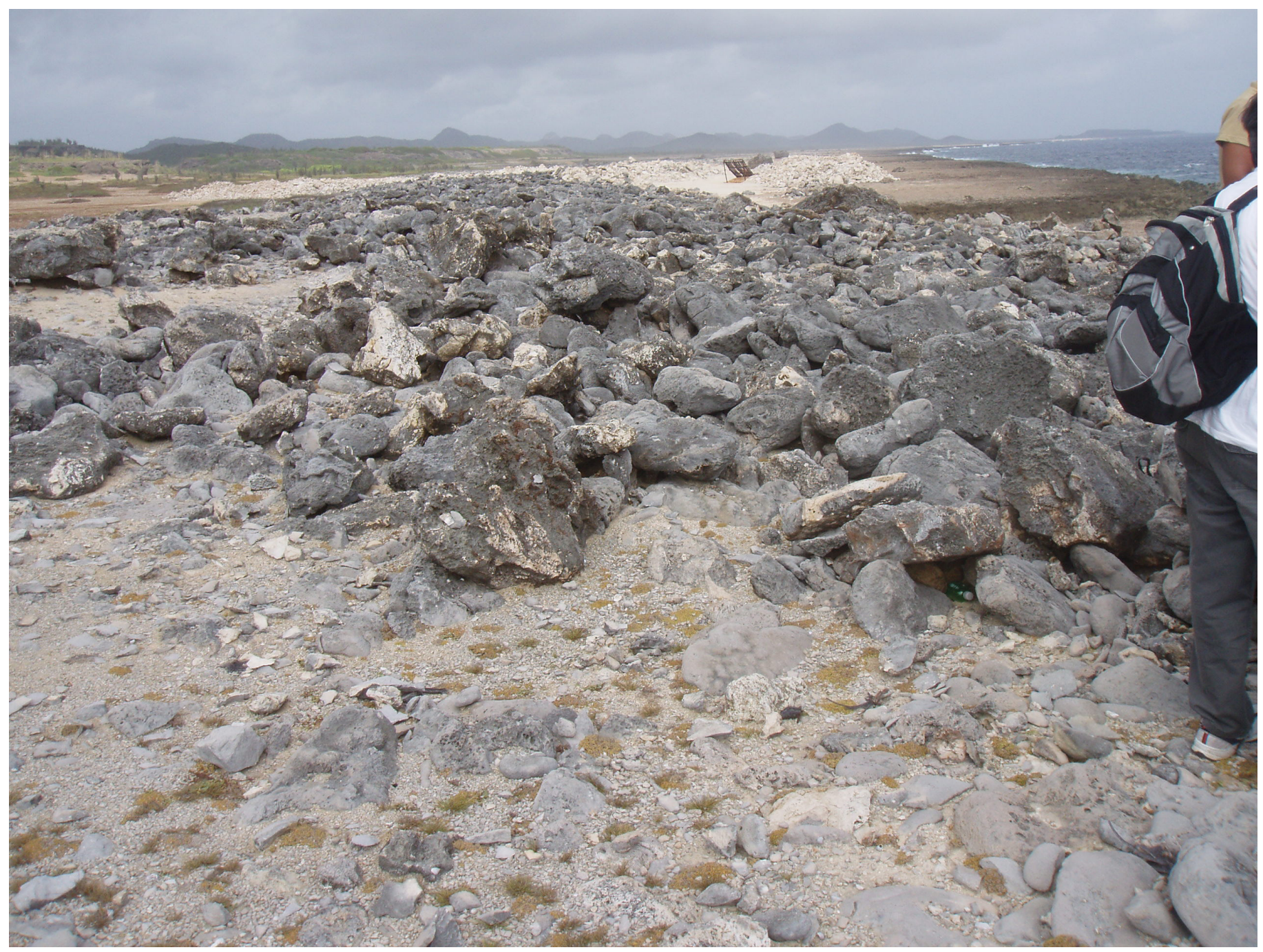

Figure 15. Panorama of landward sloping reef-rubble ridge complex on an elevated rock platform on eastern coast of Bonaire (Fig. 2, site 15).

Hugo storm surge elevation at this location was about $1 \mathrm{~m}$.

\section{Guadeloupe}

Sites visited in Guadeloupe on the northwest coast of Basse-Terre were inundated by the 1867 tsunami and sites on Grande Terre were exposed to the 1755 tsunami.

\section{Deposits Near the Shore and Near Sea Level}

In Guadeloupe, deposits near the shore and near sea level are associated with active beaches that are frequently overwashed by storm waves.
Nearly all of the beaches we visited are composed entirely of sand, only a few also contain cobbles and small boulders. For example, on the northwest coast of Basse-Terre at Point Allegre (Fig. 4, site 1), beach sediments consist of sand that includes some cobbles and fine boulders of basalt. The cobbles and boulders are eroded from the wave-cut scarp formed where the sea intersects upland alluvium. At lower elevations overwash sand is being transported across the beach and deposited into an adjacent pond that occupies a topographic low formed by upland drainage. On flanks of the uplands at elevations above the beach are isolated large basalt boulders scattered across the surface. Locally the 

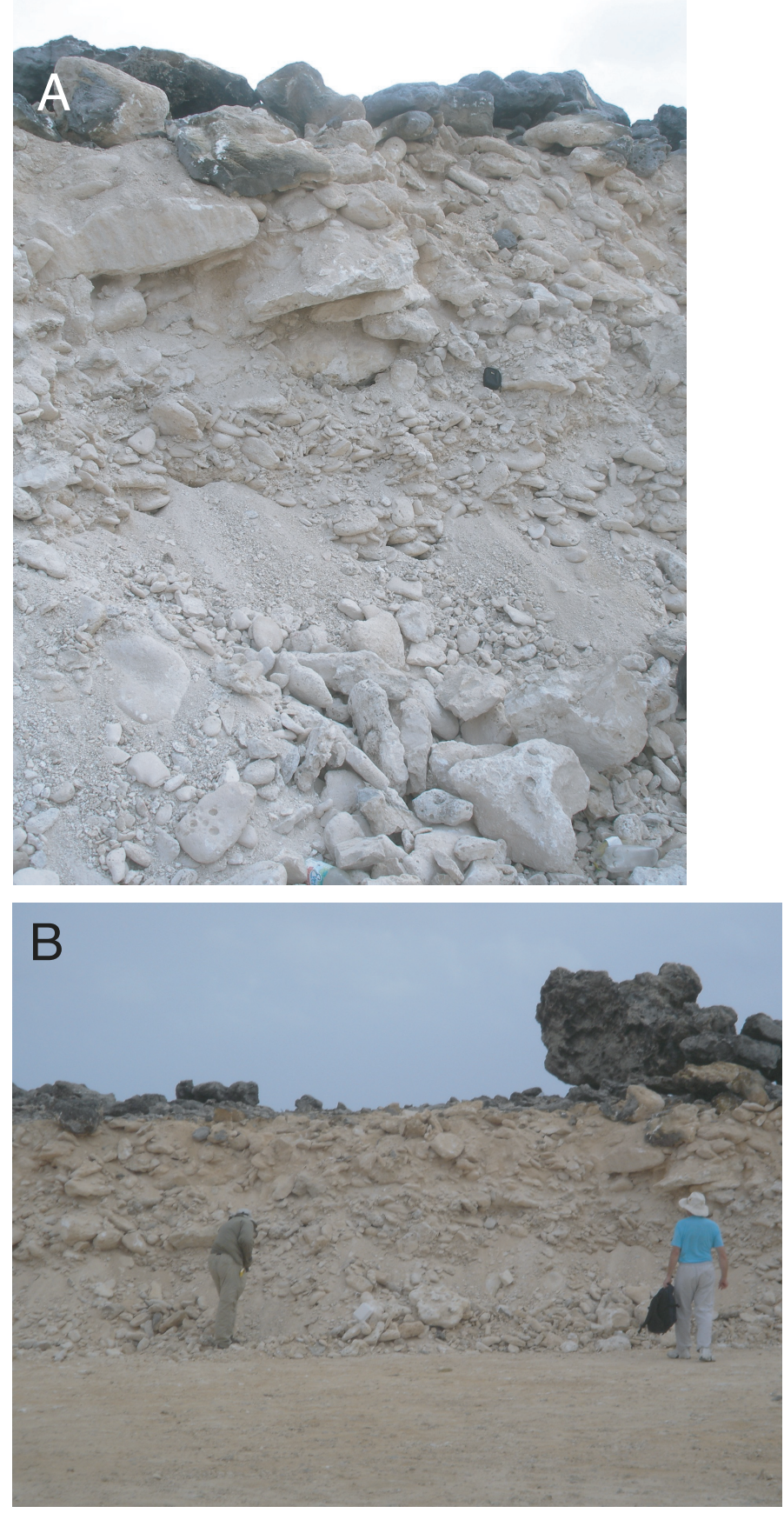

Figure 16. Mining pit on the seaward side of the reef-rubble ridge complex shown in fig. 15. The exposure shows $(A)$ clast imbrication and sorting, and $(B)$ two beds with a bounding surface and differences in clast sizes. The exposure is approximately $4 \mathrm{~m}$ high.

boulders have been moved by humans and aligned to construct traffic barriers. Whether the boulders were initially transported and deposited by storm waves or tsunamis is unclear. The relatively small size of the boulders and their relatively low elevation and proximity to the shore make them likely candidates for storm wave emplacement. Scheffers and others (2005) concluded that similar boulder fields were storm deposits and that there was no morphological evidence of impacts from Holocene or historical tsunamis on Basse Terre.

\section{Wetland Deposits}

A core taken at Plage de la Perle (Fig. 4, site 3) provided the only observations of sediments beneath a wetland in Guadeloupe. At this mangrove site, the core recovered $175 \mathrm{~cm}$ of tan and gray mud that is mottled and iron stained by root casts. The cored sediments exhibited no evidence of any sandy event deposit despite the fact that the coring site is about $60 \mathrm{~m}$ inland from the shore and the adjacent mostly barren sand backbeach showed evidence of recent inundation and landward sand transport.

\section{Slightly Elevated Terrace Deposits}

On the embayed east coast of Grande-Terre at Anse Ste. Marguerite and Anse Maurice (Fig. 4, sites 10 and 11) is a shore-parallel terrace about 30-50 $\mathrm{m}$ wide and 2-3 $\mathrm{m}$ asl (Fig. 20). Small sandmining pits in the slightly elevated deposits show that they are composed primarily of coarse sand with scattered cobbles. Roots are abundant in the mixed sand and cobble exposures, which may explain the apparent lack of stratification. Boulders and blocks are scattered across the elevated terrace surface at Anse Ste. Marguerite and some boulder and blocks also are located near the shore at the northern end of Anse Maurice. An unpaved roughly shore-parallel road follows the break in topographic slope that separates the shrub and tree covered elevated terrace from a lower, presumably younger, shore-parallel terrace of sand and cobbles that is covered by dense vines and grass. The physical characteristics that help distinguish the two terrace deposits are the greater elevation, thickness, and width of the older deposits, not their compositions. The lower terrace thins seaward and pinches out at a wave-washed 


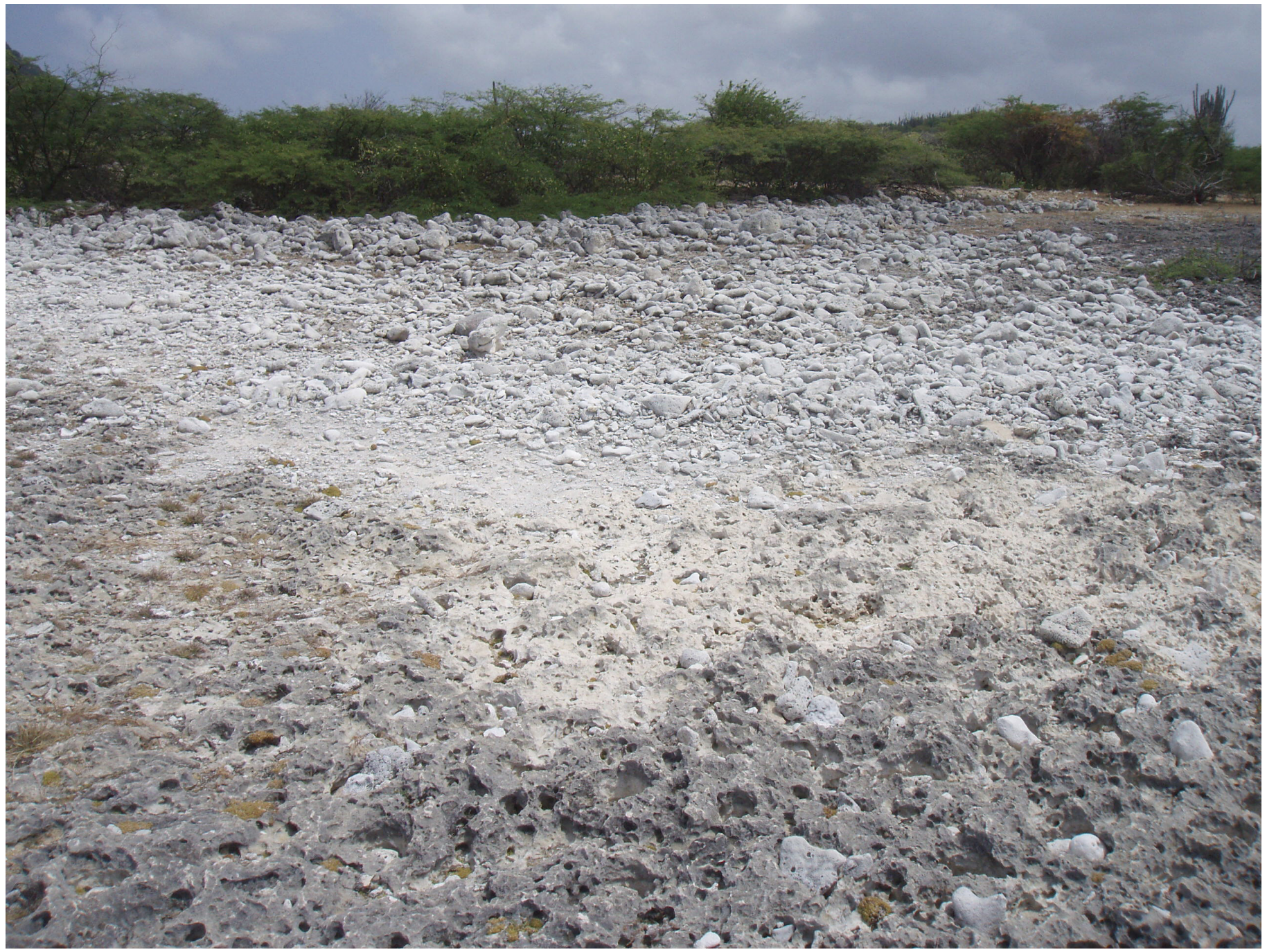

Figure 17. Apron of cobbles deposited by Hurricane Lenny on an elevated rock platform on the northwestern coast of Bonaire (Fig. 2, site 22).

barren zone of a rock platform on which are perched scattered cobbles. The frequently inundated barren zone of the rock platform merges further seaward with the intertidal and subtidal zones of the platform. Evidence of recent inundation of the low terrace is a wrack line that contains styrofoam floats, plastic bottles, and other trash. Whether the most recent inundation was by a storm or the low-amplitude tsunami of 2004 (Zahibo and others, 2005) is unknown. Scheffers and others (2005) interpreted the elevated bimodal sediments and scattered boulders as a deposit formed by a single tsunami 2500-2700 YBP.

\section{ORIGINS OF COARSE CLAST AND BIMODAL DEPOSITS}

The sizes and shapes of cobbles, boulders, and blocks at the shore cause them to respond to ocean waves differently than finer particles (Bluck, 1967, 1999; Kirk, 1980; Oak, 1984). As clast mass increases, the importance of particle suspension decreases and boulders and blocks move primarily by rolling or sliding at speeds that are less than the flow velocity (Inman, 1949).

Coarse clast deposits examined on the Caribbean islands can be grouped into ridges and ridge complexes or boulder fields depending on 


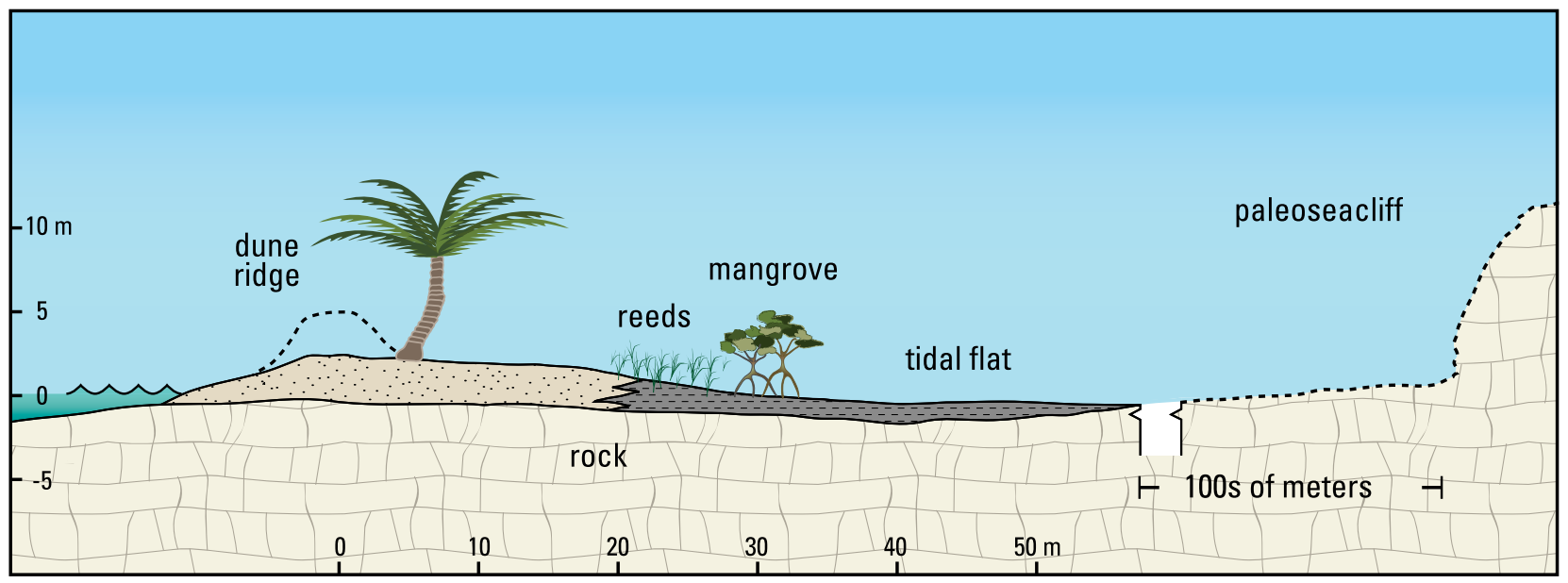

Figure 18. General topographic profile, morphology, and depositional setting of coastal plain and wetland setting.

particle spacing and the resulting degree of clast concentration. For ridges and ridge complexes, the particles are in contact with one another and exhibit fitted (packed) fabrics, whereas in boulder fields, the particles are separated, they are single layer deposits, and their respective positions do not necessarily influence subsequent movement of one another. The boulder fields also consist of blocks that are much larger than the sizes of clasts in the ridges and ridge complexes. Historical accounts of similar features formed on the margins of other ocean basins are presented as a basis for interpreting the origins of coarse clast coastal deposits on the Caribbean islands.

\section{Origins of Ridges and Ridge Complexes}

Much of the published literature on characteristics of cobble-boulder beaches comes from two distinctly different climatic and depositional settings; either mid- to high-latitude formerly glaciated coasts typically with some rocky shore segments, or low latitude tropical reefencompassed islands and atolls. On higher latitude beaches, clasts commonly are more rounded because of prior abrasion during glacial transport. In contrast, clasts from reef settings may be rounded by wave action or highly angular if they are composed of living material, such as coral colonies, that was eroded during the emplacement event.
Observations from mid- to high-latitude cobbleboulder beaches are instructive because they provide principles that can be applied to other coarse clast deposits, regardless of depositional setting. For example, Bluck (1967) found that clast imbrication is best developed on the seaward side of beach deposits where they form a zone near the height of wave runup. After initial deposition and surficial clast imbrication of storm ridges as a result of unidirectional overwash, reworking by ocean swell or waves of less intense storms produces additional imbrication and tighter clast fitting (Shelley, 1968). The resulting three-dimensional interpenetration and interlocking of clasts eventually provides framework stability that is more resistant to further reworking and helps preserve the older deposits and their associated fabrics (Bishop and Hughes, 1989).

Beach ridges and ridge complexes with dimensions, morphologies, clast sizes, and compositions similar to those observed on Bonaire have been reported for several Pacific atolls (Figs. 21 and 22). For example, Umbgrove (1947) described storm-emplaced ramparts composed of coral shingle and occasional coral boulders up to $1.5 \mathrm{~m}$ in diameter that rim numerous atolls of the East Indies. Newell (1954) reported that on Raroria, ridges comprised of sand and gravel and deposited on the reef flat by storm waves were derived from the adjacent coral reefs. The coarsest and highest ridges coincided with shore 


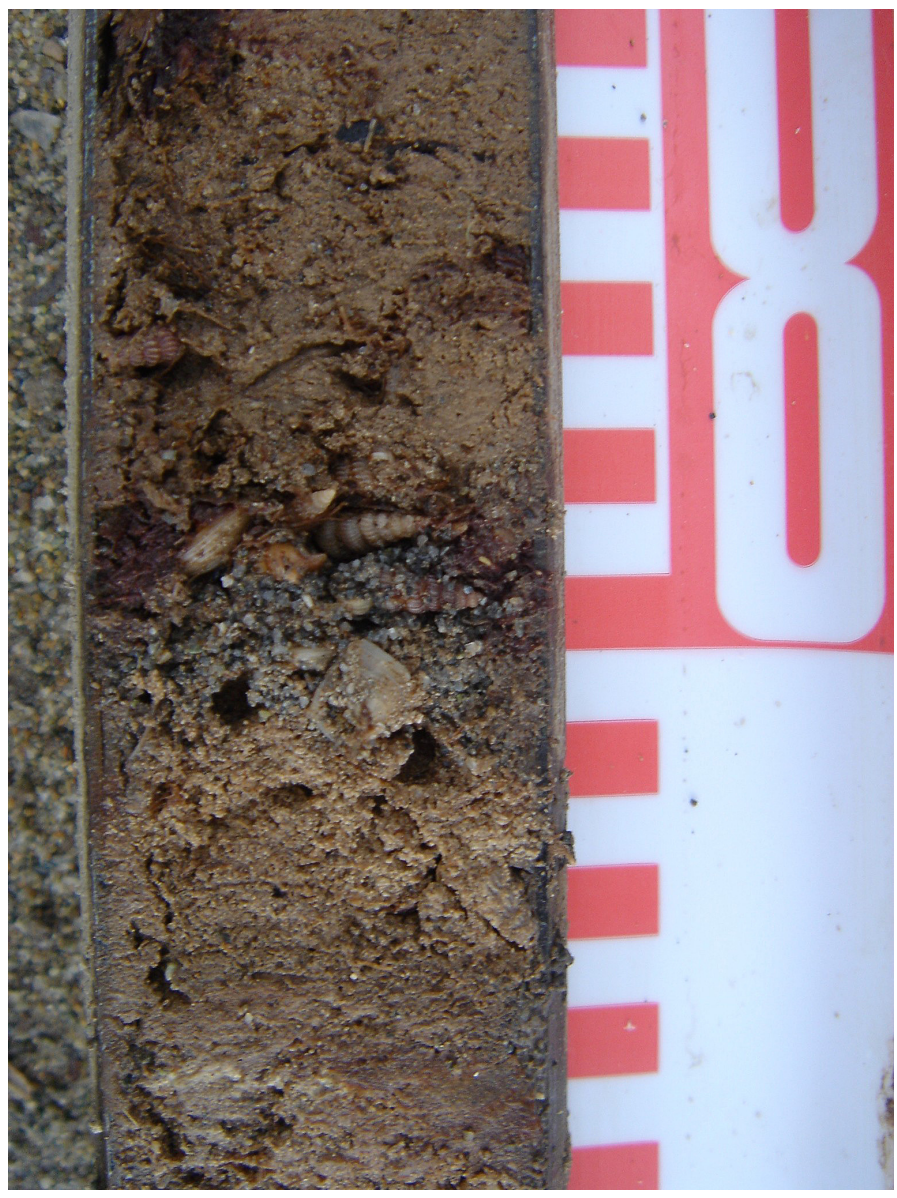

Figure 19. Core of sediments beneath wetlands at Bajura, Puerto Rico (Fig. 3, site 7) showing event deposit of sand and shells encased in laminated mud. Scale is in $\mathrm{cm}$.

segments that were at a high angle or embayed to the direction of storm wave approach. Reef-derived blocks up to $9 \mathrm{~m}$ long were observed on the reef flat and adjacent beach. McKee (1959) described coarse clast ridges near the shore and gravel sheets on the island interiors that were formed on Jaluit Atoll by an intense typhoon (Ophelia) in 1958. The pebble to boulder deposits generally were poorly sorted, had crude stratification, and exhibited fair to good clast imbrication that dipped seaward. The ridges were $15-18 \mathrm{~m}$ wide and up to $2.4 \mathrm{~m}$ high. The gravel sheets, which were up to $1 \mathrm{~m}$ thick, were composed of clasts finer than the ridges, and extended inland as much as $90 \mathrm{~m}$. McKee (1959) emphasized the winnowing of sand in the storm deposits and particle size segregation such that sandier deposits represented accumulation on lee shores or more normal wave conditions. Baines and others (1974) and Baines and McLean (1976) documented reef rubble ridges (Figure 21) and sheets constructed on Funafuti atoll by waves of Tropical Cyclone Bebe (1972) and monitored subsequent reworking of the ridges by ocean swell. The ridges were up to $4 \mathrm{~m}$ high and $37 \mathrm{~m}$ wide and terminated landward in an avalanche slope of 3$9^{\circ}$. The largest reef-derived boulder resting at the toe of the seaward face was $7 \times 3 \times 3 \mathrm{~m}$. The gravel sheets at low elevations extended inland as much as 75 m. McLean and Hosking (1991) described and illustrated wave-constructed ridges and ridge and swale complexes from atolls in Tuvalu. They reported that ridge morphologies, elevations, and clast sizes were related to wave exposure. On the windward sides of the atolls, ridges were composed of pebbles, cobbles, and platy coral rubble that were imbricated and dipped toward the ocean. Ridges with crest elevations of 3-5 m above the reef flat were asymmetrical with steeper seaward slopes and more gentle landward slopes. Where individual ridges had migrated leeward to coalesce with older topographically high features, a ridge and swale complex as much as $500 \mathrm{~m}$ wide was formed. These studies showed that ridge crest elevations and ridge morphologies depend on heights of wave runup and antecedent topography, including prior beach deposits. The rubble tracts or veneers form where pre-storm elevations near the shore are low and consequently wave runup heights are also low.

Although details are lacking, Schubert and Valastro (1976) refer to a modern storm deposited ridge complex in the southern Caribbean Sea near Bonaire. The ridge complex along the northern and eastern coasts of La Orchila Island, Venezuela, which is composed of coral rubble and shell fragments ranging in size from pebbles to boulders, is as much as $100 \mathrm{~m}$ wide and $3 \mathrm{~m}$ high.

Individual storm rubble ridges and their subsequent merging with older storm deposits (Figure 22) are part of the long-term sedimentation that constructs aggradational and progradational depositional complexes on some reef islands (Cloud, 


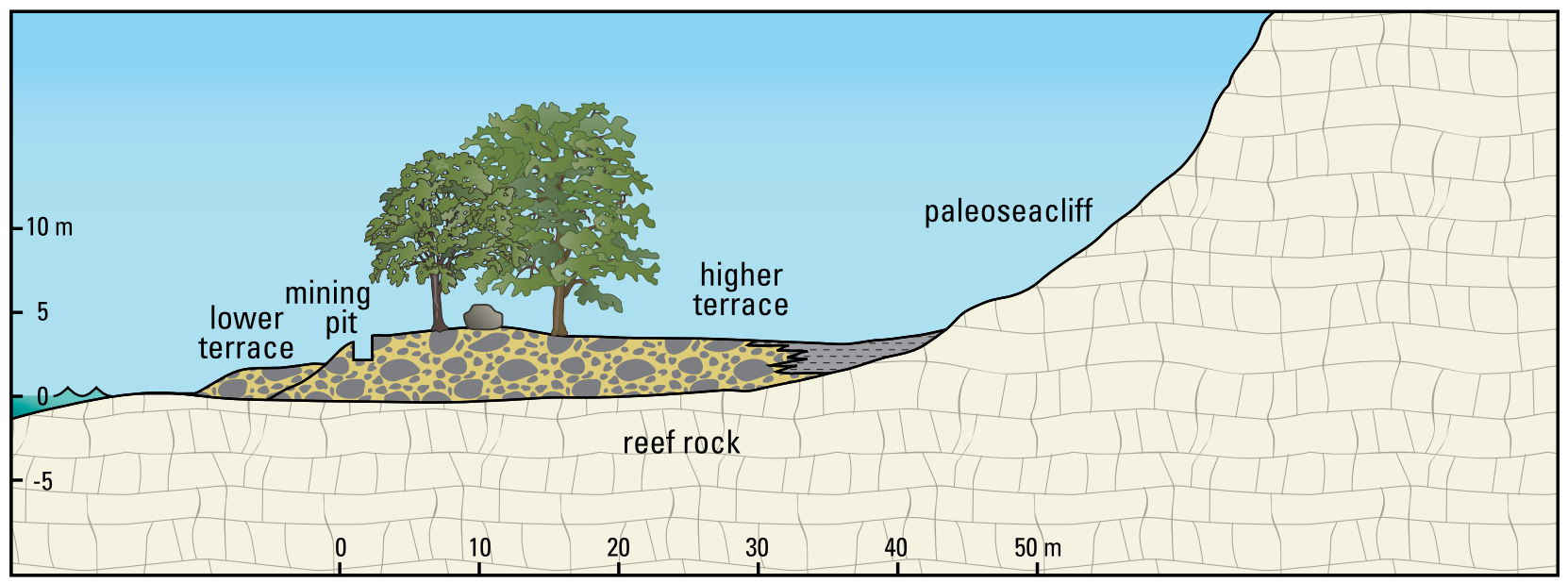

Figure 20. General topographic profile, morphology, and depositional setting of elevated terrace at Anse Ste. Marguerite on eastern side of Grande-Terre, Guadeloupe.

1952; McKee, 1959; Baines and McLean, 1976, Richmond, 1992). After reviewing a number of reports of hurricane impacts on reef islands, BaylissSmith (1988) concluded that storm waves were the only marine process capable of large volume emplacement of rubble ridges and ridge complexes, and more frequent less intense waves reworked the storm deposits into more stable features. Orford and others (1991) described the processes leading to subsequent aggradation of storm-constructed coarseclast ridges.

\section{Origins of Boulder Fields}

Boulder fields on elevated platforms or upland surfaces have the same general characteristics and distributions as those formed near sea level. An added complication is that extreme waves are required to dislodge megaclasts from rock platforms and lift them several meters above sea level onto the platform before they can be transported inland. Also there are only a few published reports of coarse boulders and blocks being transported and deposited by historical tsunamis or storm waves that can be used diagnostically to identify the depositional processes.

\section{Ocean Swell and Storm Waves}

The oldest records of boulder movement by ocean swell or storm waves are anecdotal accounts that provide limited but useful information. For example, Stevenson (1864) observed at Whalsey Skerries, Scotland, 6-ton blocks that had been quarried from their beds by wave action. He also reported that a 7.5 ton block moved laterally $22 \mathrm{~m}$ across a rock platform elevated $6 \mathrm{~m}$ asl. Sussmilch (1912) reported that storm waves in 1912 dislodged boulders and blocks from a rock platform at Bondi Beach, Australia. The largest clast dislodged was a $6 \times 5 \times 3$ m block weighing an estimated 240 tons that was transported $50 \mathrm{~m}$ across the platform and overturned.

Baines and others (1974) found that ocean swell at high spring tide was sufficient to transport large boulders from the seaward side over the crest of a high storm ridge on a Pacific atoll. According to Bishop and Hughes (1989) a 1974 storm in New South Wales, Australia transported boulders (1 $\mathrm{m} b$ axis) as much as $100 \mathrm{~m}$ inland across a rock platform and through a vertical distance of 10-15 m.

McFadgen and Yaldwyn (1984) illustrated a growing beach ridge composed of large boulders on a sub-Antarctic New Zealand island. The boulder ridge was deposited on a $25 \mathrm{~m}$ high rock platform 


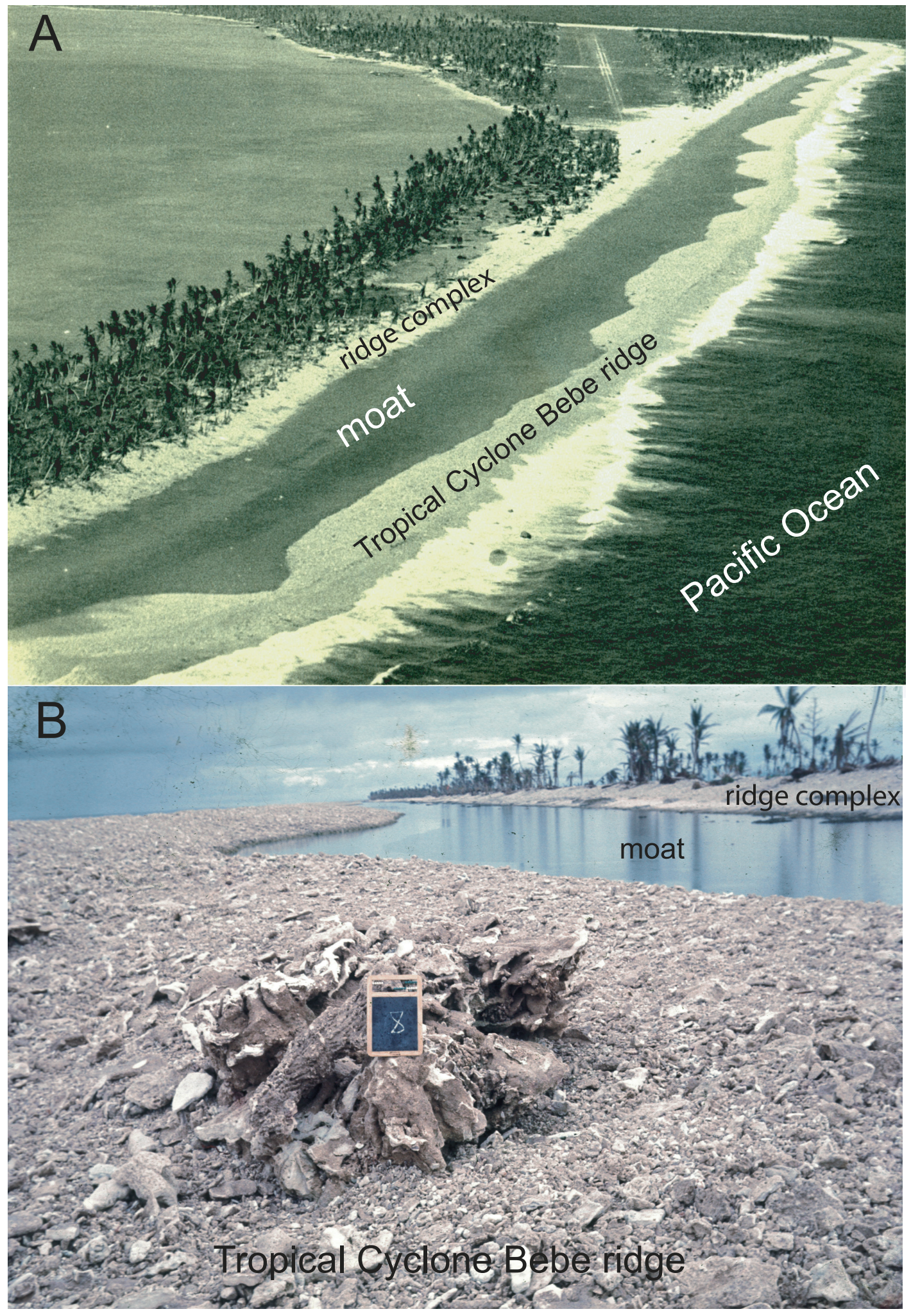

Figure 21. Coral-rubble ridge constructed by Tropical Cyclone Bebe and adjacent older ridge complex on Funafuti Atoll. (A) Air and (B) ground photographs taken by Jim Maragos in December, 1972, only two months after Bebe. Compare Bebe ridge with Hurricane Lenny ridge (figure 9) and with reworked Funafuti ridge (figure 22). 


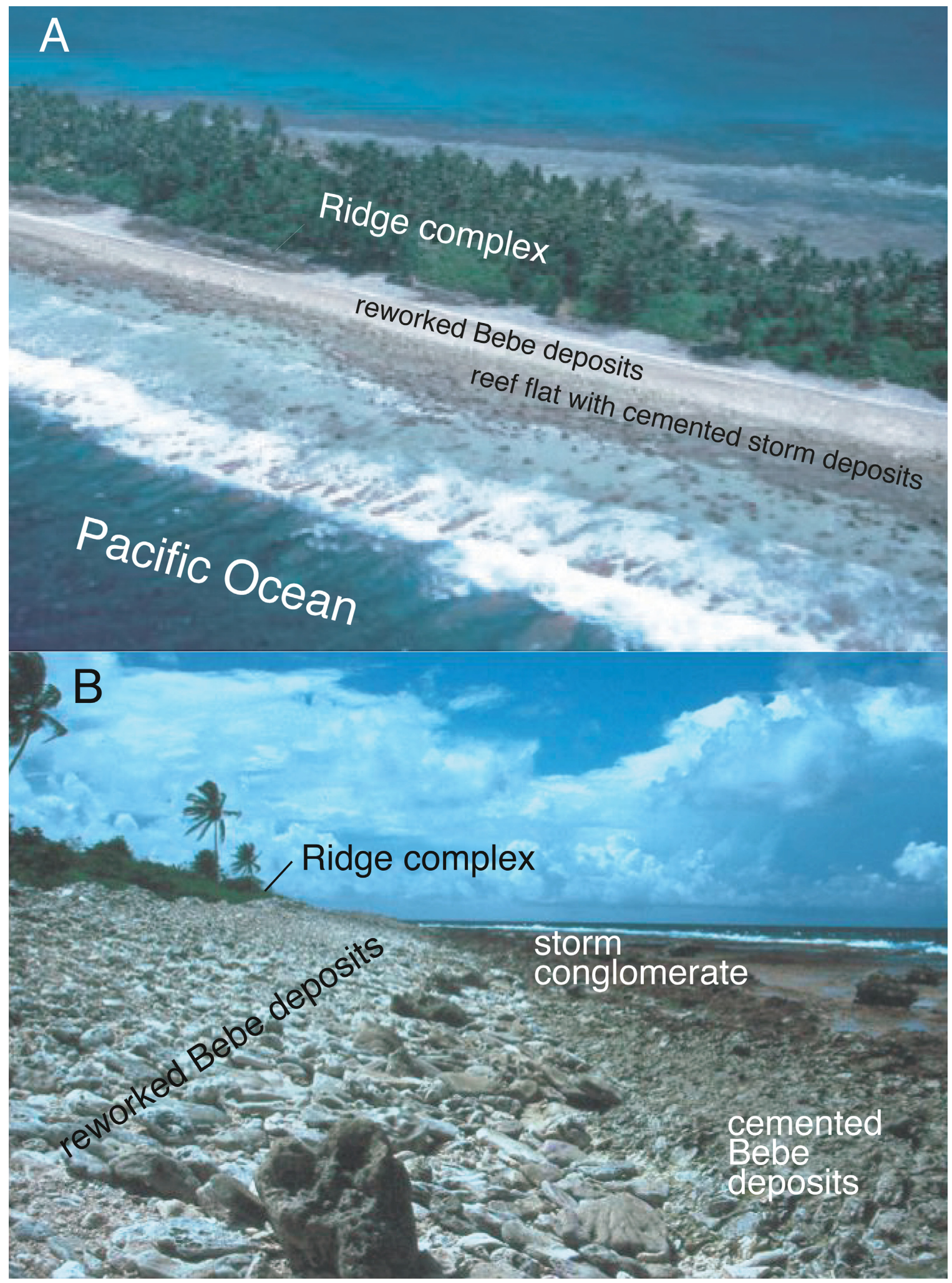

Figure 22. Coral-rubble ridge complex on Funafuti Atoll and Tropical Cyclone Bebe deposits subsequently reworked by less intense storms. The reworked Bebe ridge migrated landward and merged with the ridge complex. Basal remnants of the Bebe deposit are lightly cemented by calcium carbonate on the reef flat. (A) Air and (B) ground photograph taken by Bruce Richmond in January, 1987, approximately 14 years after Bebe. Compare with figure 21. 


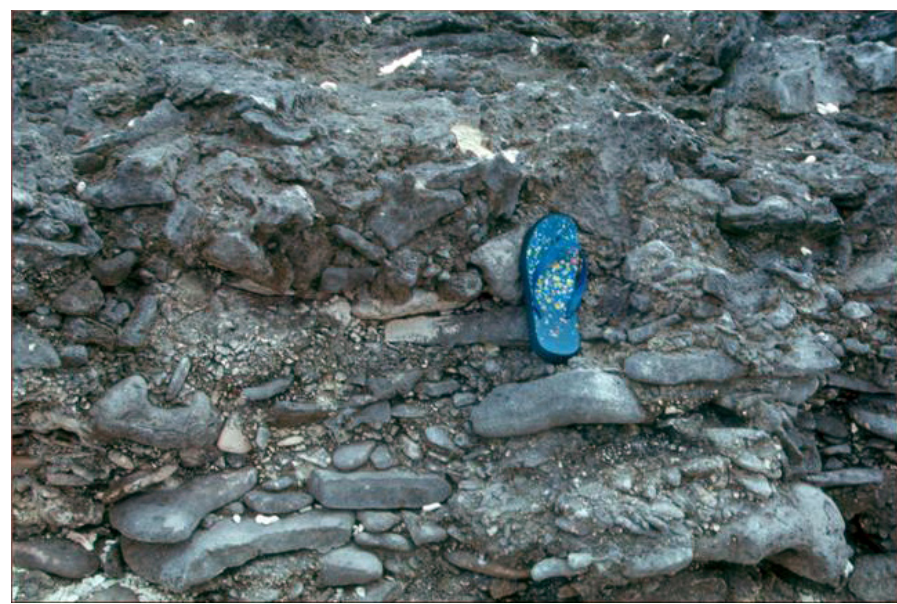

Figure 23. Exposure of polymodal reef-derived sediments deposited by storm waves on Rakahanga Atoll, Cook Islands. The deposit is cemented by calcium carbonate.

presumably by deep ocean storm waves from the Tasman Sea.

Williams and Hall (2004) and Hall and others (2006) described a series of imbricate boulder ridges and isolated blocks that were deposited on rock platforms as much as $50 \mathrm{~m}$ high along the exposed coasts of Scotland and Ireland. They relied on eyewitness accounts, trapped man-made debris, and lack of a tsunami record as evidence that at least some of the megaclasts were deposited by extreme storm waves of the North Atlantic Ocean. The ridges, which are 1-6 m thick and 3-35 m wide, are composed of clasts ranging in size from sand to $7 \mathrm{~m}$. Clast sorting was also observed with block weight decreasing and angularity increasing with elevation.

Saintilan and Rogers (2005) showed that a block quarried and emplaced on a rock platform by storm swell on the southeast coast of Australia in 1999 was one of the largest clasts at the site. The newly emplaced 15.7-ton block was moved $40 \mathrm{~m}$ from the rock platform edge and lifted to an elevation of $2 \mathrm{~m}$ asl. Saintilan and Rogers (2005) used wave parameters from nearby gauges to determine that the return frequency of the storm waves was every four years and that nearly all of the boulders at the site could be transported by waves of the same magnitudes as those recorded during the boulder transport event. The New South Wales site was one of those used by Bryant and others (1996) as evidence of tsunami boulder deposition.

\section{Tsunamis}

Reports of coastal boulders emplaced or moved by historical tsunamis are also limited in number and in the detail they provide. According to Japanese historical documents reviewed by Moore and Yoshida (2001), coral blocks up to $5 \mathrm{~m}$ in diameter were transported by the 1771 Meiwa tsunami that struck the island of Ishigakijima. Also the same 1771 tsunami constructed a set of boulder fields on the Sakishima islands of Ishigaki, Tarama, Irabu-Shimoji, and Miyako (Andrew Moore, 2006, personal communication). There are several published references to these tsunami boulder deposits, but they are written in Japanese.

Umbgrove (1947) reported that tsunamis associated with volcanic eruptions deposited large coral blocks on some beaches of the East Indies. The tsunami generated by the explosion of Krakatoa in 1883 carried a block of $300 \mathrm{~m}^{3}$ approximately $100 \mathrm{~m}$ inland from the shore.

A team of USGS scientists witnessed the 1960 tsunami wave train as it inundated Hilo, Hawaii (Eaton and others, 1961). After the water receded, they observed individual boulders weighing up to 22 tons that had been excavated from a seawall and transported inland 120-180 m without visible signs of contact with the ground. Apparently the sizes of transported boulders were limited by boulder sizes in the seawall.

Noormets and others (2002) used sequential aerial photographs to constrain the timing of emplacement of isolated blocks and rearrangement of clusters of imbricate boulders quarried from the front of a rock platform on northwest Oahu, Hawaii. Dimensions of the boulders and blocks ranged from 0.5 to $8.8 \mathrm{~m}$. They concluded that emplacement of the largest block (96 tons) was by a distant tsunami in 1946. The block subsequently moved inland $30 \mathrm{~m}$ twice, but along different trajectories. At least one of 
those 30-m jumps was caused by long-period swell from a winter storm that flooded the rock platform.

Goff and others (2006) investigated a discontinuous veneer of 1-3 $\mathrm{m}$ boulders and sand transported and deposited by a 1975 locallygenerated tsunami on the island of Hawaii. They reported that the boulders and sand both showed landward fining over the same distance and both terminated near the same distance from the shore. A landward decrease in clast size from blocks to fine sand also was reported for deposits on the reef flat of Rangiroa, Tuamotu (Bourrouilh-Le Jan and Talandier, 1985).

Tsunami scientists investigating the impacts of the 2004 Indian Ocean tsunami on the west coast of Thailand observed a field of boulders that may have been emplaced and moved across an intertidal rock platform by the tsunami at Pakarang Cape (Bretwood Higman, 2006 personal communication).

\section{Bimodal deposits}

Bimodal coastal deposits are a function of available clast sizes in the nearshore sediments and the history of transport and deposition of individual clasts. They are not diagnostic of a particular type of wave process although clast textures (size, shape, roundness) and internal organization (packing, sorting, and stratification) may provide important clues to their origins (Carr and others, 1970; Williams and Caldwell, 1988). Furthermore, interstitial particles within gravel beaches tend to be smaller than those at the surface because smaller particles infill the larger subjacent clasts that form the framework (Bluck, 1967).

The degree of sorting of polymodal deposits is related to initial rates of sedimentation and subsequent history of sediment reworking. Extremely rapid deposition (hours) of large volumes of mixed sediment sizes typically results in poor sorting because the high concentrations of large clasts interfere with the sorting processes and there is insufficient time for waves to organize the clasts.
Polymodal heterogeneous coastal deposits consisting of clasts ranging in size from boulders or cobbles to sand that accumulated as a result of storm waves (Fig. 23) are common (Newell, 1954; Bluck, 1967, 1999; Kirk, 1980; Carter and Orford, 1981; Woodroffe, 1994; FitzGerald and others, 1994; Neal and others, 2003). In contrast to these examples of storm-generated bimodal deposits, Kelletat and others (2004), Scheffers and others (2005), Scheffers (2005), and Scheffers and Kelletat (2006) emphasized bimodal deposits as being diagnostic evidence of a tsunami. For example, Scheffers and others (2005) interpreted the composition and morphology of bimodal deposits on the east coast of Guadeloupe as evidence of tsunami deposition. Although radiocarbon dates from these deposits span a range of nearly two thousand years, Scheffers and others (2005) concluded that a single tsunami about 2500-2700 YBP was responsible for the boulder and elevated ridge deposition. The relatively low elevation of the bimodal deposits within the range of storm surge elevations, their terrace morphology, the eastern exposure to frequent hurricane waves, and the total volume of accumulated sediment make a storm-dominated depositional complex of multiple events a likely explanation of their origin.

\section{DISCUSSION}

\section{Deposit Origins}

It is clear from the preceding discussions that extreme waves capable of causing substantial coastal erosion and sediment transport are common in the Caribbean Sea. What remains unclear are the signatures of tsunami and storm deposits that are composed of clasts larger than sand and in particular clasts that are classified as boulders and blocks (Blair and McPherson, 1999). Consequently the origins of many of the deposits we observed on Bonaire, Puerto Rico, and Guadeloupe are still uncertain because the information available to interpret the depositional processes was limited by rapid reconnaissance. All of the features we 
observed with known origins were formed by recent storms.

Scheffers (2002) used the low frequency of hurricanes impacting the $\mathrm{ABC}$ (Aruba, Bonaire, Curacao) islands to exclude storms as an agent of coarse clast deposition. She also concluded that the narrow shape and low elevation of the storm ridge deposited by Hurricane Lenny were evidence that the broad coarse clast ridges near the shore and up to $3 \mathrm{~m}$ asl were either entirely tsunami deposits or a tsunami deposit that was later modified by storm armoring. No other physical evidence was presented to support the tsunami hypothesis and important evidence that supports multiple wave events, such as storms, was not considered. Radiocarbon dates that supposedly cluster around 400-500 BP, 1500 $\mathrm{BP}$, and $3500 \mathrm{BP}$ were used as evidence of three individual tsunami events. However, the distribution of radiocarbon dates grouped by shoreline sector around Bonaire (Scheffers, 2005) span thousands of years, which is compelling evidence of long-term coastal deposition by many extreme wave events. Furthermore, in many places mining has destroyed the landward parts of the deposits so the entire age ranges of the deposits is unknown because the oldest sediments were not available for dating. As for the boulder and block deposits, Scheffers $(2002,2005)$ concluded that because neither Hurricane Lenny nor Hurricane Ivan emplaced blocks on the rock platforms of the $\mathrm{ABC}$ islands, the boulders were quarried and transported by tsunamis. The results of the Nott (1997) equations also were used to conclude that hurricane waves were incapable of emplacing the boulders.

On the basis of similarities in coastal depositional features (ridges, ridge complexes, boulder fields) and clustering of radiocarbon dates for these features, Scheffers and others (2005), Scheffers (2005), and Scheffers and Kelletat (2006) concluded that since $4500 \mathrm{YBP}$, (1) 3 to 6 separate megatsunamis impacted the Caribbean islands, and (2) those individual tsunamis were responsible for constructing the coarse clast coral rubble ridge complexes and boulder fields throughout the Caribbean region. However, the chronological tsunami distribution map of Lander and others (2002) does not easily support this conclusion of regional impacts by individual tsunamis. Instead it shows that during the past 500 years only the 1755 and 1867 tsunamis were reported at multiple locations in the Caribbean and there is no evidence that they were responsible for massive movement and organization of coarse coral-reef rubble. The historical locally generated tsunamis have had limited impacts, both in their areal extent and in their ability to cause significant changes in the landscape.

Large-volume coarse clast accumulations and sand blankets interpreted as paleo-tsunami deposits, such as those described respectively by Moore and Moore (1988), Scheffers (2002, 2005), Scheffers and others (2005), Switzer and others (2005), and Scheffers and Kelletat (2006) that are several meters thick, internally exhibit multiple layers with bounding surfaces, and are 10 s to 100 s of meters wide are not likely products of a single or a few tsunamis. We conclude they are probably the composite record of long-term coastal processes spanning centuries to millennia because they have morphological, sedimentological, and stratigraphic attributes that favor deposition by multiple highfrequency waves. Evidence of frequent waves includes ridge complex morphologies, lateral and vertical textural trends, internal stratification, and the extremely large volumes of accumulated sediments. Some of the same physical criteria were used by Hayne and Chappell (2001) to establish storm origins of beach ridges and to estimate storm frequency on the north coast of Australia.

A diagnostic feature of coarse clasts deposited by storm waves is the construction of shore-parallel ridges and ridge complexes (Umbgrove, 1947; Cloud, 1952; Newell, 1954; McKee, 1959; Maragos and others, 1973; Baines and others, 1974; BaylissSmith, 1988, McLean and Hosking, 1991; Scoffin, 1993; McLean and Woodroffe, 1994; Scheffers, 2005). In contrast, there are no known reports of historical tsunamis depositing a high, linear ridge of coarse clasts near and parallel to the shore. The 
coarse clast ridges deposited by Tropical Cyclone Ophelia (McKee, 1959), Tropical Cyclone Bebe (Baines and others, 1974), and by Hurricane Lenny (Scheffers, 2005) represent deposit morphologies of a single storm on a reef flat that had no antecedent topography (prior beach or ridge) to influence ridge construction. Although sediment transport by strong alongshore currents was demonstrated for the Hurricane Lenny ridge, the ridge formed and has grown as a result of many breaking waves. The roughly linear shore-parallel concentration of clasts is a result of maximum storm-wave runup and deposition at elevations above runup of nonstorm waves at high tide (Bluck, 1967; Hayne and Chappell, 2001).

Another diagnostic feature of storm-wave deposits is the steep avalanche slope (Figs. 7 and 21) on their landward sides (McKee, 1959; Baines and McLean, 1976; Scoffin, 1993; FitzGerald and others 1994; Orford and others, 2002). The avalanche slope is constructed by bedload transport of clasts during overwash across the ridge and flow separation into deeper water landward of the ridge.

The external and internal organization of coarse clasts and resulting sedimentological fabric of the ridge deposits also provide evidence of high-frequency wave processes. Although clast imbrication is not diagnostic of a particular depositional environment or hydrodynamic process, imbricated surficial clasts on beaches are common products of clast fitting as a result of frequent wave swash and backwash (Bluck, 1967). The imbricated clasts dip seaward (Fig. 8) and as wave-influenced deposits aggrade, an internal imbricate fabric is formed (Figs. 14 and 16A). Other evidence of clast sorting by multiple waves includes steep seaward dipping or vertically stacked graded beds that exhibit well-defined stratification (Figs. 14 and 16B). The stratified beds are products of lateral accretion and aggradation by multiple storm waves that periodically add reef rubble to the progradational complex. The ridge complex deposits also exhibit bedding plane surfaces that separate sedimentary units that have distinctly different clast sizes and fabrics (Fig. 16B). The bounding surfaces are disconformities that may represent substantial hiatuses in sedimentation.

Finally, the geometries and overall dimensions of the coarse clast deposits and total volumes of sediment stored in them are evidence of multiple storm-wave events. The coarse clast ridges and ridge complexes in the Caribbean region extend continuously inland 10 s to 100 s of meters from the shore and they are several meters thick. Although precise volumetric estimates of the deposits have not been made, it appears that they can contain several hundred cubic meters per meter of beach. The total volumes of sediment deposited in the ridges and ridge complexes likely exceed the capacity of a few waves to entrain and transport sediment, especially large clasts. A few waves, such as would occur during a tsunami, is not a reasonable explanation for construction of broad, thick ridges and ridge complexes composed of stacked and internally organized coarse clasts.

\section{Elevated Deposits}

It is uncertain why rubble ridge complexes and massive blocks are stranded on rock platforms (Bonaire) or banks of bimodal sediments are perched on steep slopes (Guadeloupe) several meters above sea level and out of the reach of normal waves. Some blocks may be remnants of clasts detached from the ancestral sea cliff during an earlier highstand in sea level. However, that is not a likely explanation for most of the boulder fields because the largest blocks are closest to the active sea cliff and not the ancestral sea cliff, which is much farther from the sea. There are several possible explanations, some requiring long-term vertical movement of the land or sea.

One possible explanation is that the elevated platforms are the result of tectonic uplift that has raised the coarse clast deposits above the height of normal waves. Long-term uplift has been reported for the northern part of Bonaire (Alexander, 1961), which might explain the ridge complexes and 
boulder fields on elevated platforms, but the base elevations of 5 to $6 \mathrm{~m}$ asl and young ages of the deposits would require rapid rates of uplift that are unrealistic. The late Quaternary tectonic stability of Guadeloupe is undetermined.

The rubble ridge complexes and some of the blocks may be abandoned storm wave deposits that formed during a mid-to-late Holocene highstand in sea level. GIA model results indicate that the mid-Holocene highstand was not manifested in the Caribbean region because it is located on the margin of the Laurentide forebulge and there are no sea level records from the region that show a higher than present Holocene sea level. However, the Holocene sea level curves showing a monotonic rise that have been published for the Caribbean (Milne and others, 2005) are based on subtidal elevations that preclude establishing a Holocene sea level higher than present. Furthermore, it appears that important information regarding elevations and ages of coastal deposits on the Caribbean islands is being ignored, that perhaps should be considered as part of the sea level history.

Another explanation of the perched coarse clast deposits is that they are the result of platform or slope flooding by extreme wave events under present sea level conditions. Although extreme storm waves are capable of moving blocks on the platforms (Fig. 10, Scheffers, 2005) or depositing thin gravel aprons (Fig. 16), the elevated ridge complexes do not show evidence of active sediment accumulation or recent reworking by storm waves.

\section{CONCLUSIONS}

Considering our observations from Bonaire and evidence from Pacific atolls, we conclude that coral rubble ridges near sea level that are a few meters thick and a few 10s of meters wide and terminate in avalanche slopes were constructed by multiple wave events dominated by storms. Similarly, the composite rubble features up to $4 \mathrm{~m}$ thick and $80 \mathrm{~m}$ wide on elevated rock platforms also are interpreted as ancestral depositional complexes constructed by multiple wave events. The origins of extensive boulder fields on east Bonaire are uncertain and will require additional investigation and analysis before their origin can be determined.

Based on our reconnaissance observations in Puerto Rico, the wetland sites visited with the most promise for additional paleotsunami investigations are East Bajura, Parque Aguadilla, Punta Cucharas, and Palmas del Mar. Of the deposits examined in Puerto Rico, the thin gray sand layer with marine shells encased in tan laminated mud that was recovered at East Bajura has the greatest potential of being a paleotsunami deposit.

Although substantially less time was spent examining coastal deposits on Guadeloupe than on Bonaire or Puerto Rico during our March 2006 reconnaissance study, preliminary evidence suggests that it does not provide the diversity of settings and exposures to extreme waves that will be required to establish criteria for recognizing coarse clast tsunamis and storm deposits. Despite historical accounts of tsunamis striking the northwest and south sides of the island, their is no clear evidence of tsunami deposits, nor are there accumulations that appear to be likely tsunami deposits. The ridge of bimodal sediments at Anse Ste. Marguerite has a morphology, composition, and accumulation volume that are consistent with long-term storm-dominated coastal plain deposition, not deposition by a few tsunamis.

\section{FUTURE ACTIVITIES AND RESEARCH DIRECTIONS}

Our discussions in the field with geologists and wave modelers who have published on tsunami research, our observations and preliminary interpretations of coastal deposits on Bonaire, Puerto Rico, and Guadeloupe, and a review of the available literature provide a basis for identifying future research activities. Following are some of the important geological tasks that will improve assessment of the tsunami hazard in the Caribbean region. 


\section{Additional Field Investigations}

Data from additional field sites in the Caribbean are needed to accomplish two primary objectives. The first objective is to increase our exposure to and knowledge of Caribbean coastal deposits with the intent of understanding better: (1) the evidence for paleotsunamis, and (2) the types of reef-derived deposits formed by storms and tsunamis. Because the Virgin Islands (St. Croix, St. John, St. Thomas) are U.S. territories with historical records of tsunami impacts, they should receive high priority for future field investigations.

The second objective of additional fieldwork is to build on the reconnaissance work summarized in this report and to begin developing an inventory of deposit characteristics that will eventually lead to criteria that can be used to identify paleotsunami deposits and extend the historical record to improve tsunami risk assessment. Based on preliminary work in Puerto Rico, the East Bajura site holds the most promise for comparing possible tsunami and storm deposits. In Bonaire, the diversity of bimodal coastal deposits, their surface exposures, potential internal exposures related to mining, and their accessibility make them ideal candidates for examining coarse clast deposits with the intent of understanding the mechanisms of emplacement and post-emplacement reworking.

Improved understanding of extreme wave processes also could be accomplished by reconnoitering other islands, such as Jamaica, the Grand Caymans, and the Bahamas, where anomalous coarse clast coastal deposits have been reported (Robinson and others, 2006; Jones and Hunter, 1992; Hearty, 1997) and interpreted by some to be the products of tsunamis (Kelletat and others, 2004). The Bahamas are not part of the Caribbean region and their risk to tsunami hazards is substantially lower than their risk to hurricane waves. Nevertheless, bimodal sand and boulder deposits and megaclasts have been reported on Eleuthera (Hearty, 1997) and Long Island that have been attributed to tsunami processes (Kelletat and others, 2004). These coarse clast deposits present an opportunity to broaden the inventory of tropical coarse clast deposits, to examine sites where paleotsunami deposits have been reported, and to test concepts developed for coarse clast deposits in the Caribbean Sea. A subtask of this activity would be examining reports on inundation heights of historical storm surges for the Caribbean islands visited and compilation of eyewitness accounts for recent storms that are similar to those presented in tsunami catalogs.

Because our research in the Caribbean region is about tsunami hazards and because evidence of past extreme wave events involves boulders and blocks, it is important to investigate boulders that were transported and deposited by historical tsunamis. Several options are available where the historical record is unequivocal and where colleagues who have already conducted preliminary investigations are available for collaboration. For example, the 1771 tsunami reportedly transported boulders in Japan (Andrew Moore, 2006, personal communication), the 1946, 1960, and 1975 tsunamis each moved boulders in the Hawaiian islands (Noormets and others, 2002; Eaton and others, 1961; Goff and others, 2006), and the 2004 Indian Ocean tsunami may have constructed a boulder field in Thailand (Bretwood Higman, 2006, personal communication). Additional information about the 2004 tsunami boulder deposits in Thailand may be available in the near future (Wanna Phyo, 2006, personal communication).

\section{Morphology, Sedimentology, and Origins of Coarse Clast Caribbean Coastal Deposits}

Felton (2002) and Felton and others (2006) described detailed analytical field techniques that allowed them to evaluate widely conflicting hypotheses regarding the origins of elevated boulder deposits in Hawaii. The thick coarse clast marine deposits had been attributed previously by various authors to (1) a mega tsunami, (2) uplifted beaches, (3) multiple events, (4) surficial slope processes, 
and (5) artifacts of human occupation. Their systematic approach combined deposit composition and fabric, facies architecture, and geometries to establish a basis for genetic interpretations. Despite their thorough approach, it did not include the total volume of sediment contained in the deposit and comparisons with historical tsunami- and stormgenerated beach deposits.

Perhaps an even more powerful approach to interpreting the origins of coarse clast deposits would be combining the sedimentological analyses of Felton (2002) and Felton and others (2006) with examination of the morphologies, facies architecture, and geometries and total volume of modern coarse clast coastal deposits produced by known tsunamis and storms. Although only a few modern coarse clast tsunami deposits have been reported, they have common characteristics that provide a basis for a provisional depositional model. There are many reports of coarse clast storm deposits composed of coral rubble. Those from the Pacific region (Umbgrove, 1947; Newell, 1954; McKee, 1959; Stoddart, 1971; Maragos and others, 1973; Baines and McLean, 1976; Bayliss-Smith, 1988; Stoddart and others, 1990; Scoffin, 1993) provide important information about coral rubble emplacement on reef flats and reworking. Several sites from the North Atlantic and North Sea have been described where storm waves have detached, transported, and deposited megaclasts as ridges and fields on cliff tops as much as $50 \mathrm{~m}$ asl (Williams and Hall, 2004; Hall and others, 2006).

Additional research is needed to develop a systematic sedimentological approach to deposit analysis and a set of criteria for interpreting the origins of extreme wave deposits. Important considerations for the Caribbean region and elsewhere are present elevation of the deposits, age of the deposits, relative sea-level history (tectonic or eustatic motion) since deposition, topography, composition, and induration of the antecedent surface. Two end-member sedimentation models could be used to help evaluate whether the ridge complexes on elevated platforms were deposited (1) by high frequency waves and abundant sediment supply under conditions of prolonged elevated water levels (platform flooded by mid-Holocene highstand), or (2) episodic extreme wave events that rapidly added coral rubble (storm punctuated platform flooding and static sea level). If the former model is correct, then there should be wide segments of the ridge complex with similar textures and internal structures and possibly cementation of basal deposits, whereas if the latter model is correct, then there should be numerous internal discontinuities.

\section{Characterization of Coarse Clast Tsunami and Storm Deposits}

An ongoing task of the USGS tsunami research project is to develop physical criteria that can be used to help distinguish storm and tsunami deposits in those regions where both processes occur, although storms may predominate because of their greater frequency of occurrence. As part of that effort, a provisional identification of criteria that may be useful to differentiate sandy storm and tsunami deposits was recently completed (Morton and others, in press). What is now needed is a comparable first comparison of physical attributes of coarse clast tsunami and storm deposits that would serve as a field guide.

Kelletat and others (2004) used deposit shape (chevrons), deposit composition (mixed sand and gravel), and a barren zone between the coarse clast deposits and the shore as evidence of a tsunami. None of these criteria are diagnostic of a tsunami and there are well-documented examples of these same features being produced by historical storms. Our preliminary examination of the Caribbean coastal deposits indicates that deposit morphologies, external and internal clast organization, and deposit volumes may be a basis for distinguishing between coarse clast storm and tsunami deposits. This task would be a derivative of comparing modern coarse clast storm and tsunami deposits (see previous tasks) and would be integrated with those tasks. 


\section{Modeling Coarse Clast Competence, Capacities, and Deposits of Tsunamis and Storm Waves}

Considering the common use of the Nott (1997, 2003) equation results as evidence for tsunami emplacement of coarse clast deposits, there needs to be an independent evaluation of the basic assumptions of the equations and application of the results. This could lead to modification of the equations by inclusion of other terms or development of improved equations that rely on alternative assumptions, such as critical forces and mode of transport. For example, Noormets and others (2004) carefully compared the dynamic pressures and transport characteristics of long-period swell (storm waves) and turbulent bores (tsunami waves) and applied their results to the historical emplacement and movement of megaclasts in Hawaii. Their analytical methods may be preferred to those of Nott. The equations of Lorang (2000) may also have aspects that would improve overall prediction of boulder size transport considering wave height, wave period, runup elevations, and swash velocities.

Other important wave mechanics issues that will require additional research and modeling have to do with the volume of sediment of different sizes that can be emplaced by a single extreme-wave event (storm or tsunami) and the most likely geometry of the deposit produced by that event. This would involve identifying the theoretical upper limits of clast size (competence) and volume of sediment (capacity) for historical tsunami and storm waves. Some aspects of this research may be beyond current capabilities because it would require determining how particle-to-particle interference of large clasts in the bottom boundary layer would influence entrainment, transport, and deposition.

\section{Hazard Vulnerability Analysis and Risk Assessment}

One of the principal objectives of the Caribbean Region tsunami project is the integration of field and laboratory geological approaches to hazard vulnerability analyses and risk assessments. Therefore the emphasis of this activity would be coordination of the paleotsunami fields investigations and land-based hazard risk assessments (Geist and Mercado, 1999; Bush and others, 2001) with results of tsunami source geophysical investigations in the Caribbean Sea being conducted by Uri ten Brink (USGS, Woods Hole) and tsunami attribute modeling of the sources being conducted by Eric Geist (USGS, Menlo Park). Model results of expected local tsunami characteristics and propagation directions from potential earthquakes and landslides in the Caribbean would provide a basis for focusing field efforts in those areas that have the highest risk for tsunami impact and the greatest vulnerability considering the local setting.

\section{ACKNOWLEDGEMENTS}

We thank Anja Scheffers, Sander Scheffers, Dieter Kelletat, Juan Carlos Moya, Narcisse Zahibo for scientific and cultural discussions and for serving as field guides to study sites. We also thank Theresa Fregoso for organizing the GPS and photographic data, Russell Peterson for preparing the location maps, and Betsy Boynton for preparing the illustrations. Uri ten Brink provided the template for figure 1 . The report was improved by the critical reviews of James Goff and David Bush. 


\section{REFERENCES}

Alexander, C. S., 1961, The marine terraces of Aruba, Bonaire, and Curacao, Netherlands Antilles. Annals of the Association of American Geographers, v. 51, p. 102-123.

Baines, G. B. K., Beveridge, P. J., and Maragos, J. E., 1974, Storms and island building at Funafuti Atoll, Ellice Islands. In: Proc. 2nd International Coral Reef Symposium, p. 485-496.

Baines, G. B. K., and McLean, R. F., 1976, Sequential studies of hurricane deposit evolution at Funafuti atoll. Mar. Geol., v. 21, p. M1-M8.

Bates, R. L., and Jackson, J. A., 1987, Glossary of geology. American Geological Institute, Alexandria, VA.

Bayliss-Smith, T. P., 1988, The role of hurricanes in the development of reef islands Ontong Java atoll, Solomon Islands. Geographical Journal, v. 154, p. 377-391.

Bishop, P., and Hughes, M., 1989. Imbricate and fitted fabrics in coastal boulder deposits. Geology, v. 17, p. 544-547.

Blair, T. C., and McPherson, J. G., 1999, Grain-size and textural classification of coarse sedimentary particles. Jour. Sed. Research, v. 69, p. 6-19.

Bluck, B. J., 1967, Sedimentation of beach gravels; examples from South Wales. Jour. Sed. Petrology, v. 37, p.128-156.

Bluck, B. J., 1999, Clast assembling, bed-forms and structure in gravel beaches. Trans. of the Royal Society of Edinburgh, Earth Sciences, v. 89, p. 291-323.

Blumenstock, D. I., Fosberg, F. R., and Johnson, C. G., 1961, A resurvey of typhoon effects at Jaluit Atoll in the Marshall Islands. Nature, v. 189, p. 618-620.

Bourrouilh-Le Jan, F. G., and Talandier, J., 1985, Sedimentation et fracturation de haute energie en milieu recifal: Tsunami, ouragans et cylones et leurs effets sur la sedimentologie et la geomophologie d'un atoll: motu et hoa, a Rangiroa, Tuamotu, Pacifique SE. Mar. Geol., v. 67, p. 263-333.

Bryant, E. A., Young, R. W., and Price, D. M., 1996, Tsunami as a major control on coastal evolution, southeastern Australia. Jour. of Coastal Research, v. 12, p. 831-840.

Bush, D. M., 1991, Impact of Hurricane Hugo on the rocky coast of Puerto Rico. Jour. of Coastal Research Special Issue 8, p. 49-67.

Bush, D. M., Richmond, B. M., and Neal, W. J., 2001, Coastal zone hazard maps: Eastern Puerto Rico. Environmental Geosciences, v. 8, p. 38-60.
Capacete, Martín \& Associates, 1978, Potential sand sources in Puerto Rico and environmental impact assessment of sand mining. Prepared for U.S. Army Engineer District Jacksonville, Florida, 156p.

Carr, A. P., Gleason, R., and King, A., 1970, Significance of pebble size and shape in sorting by waves. Sed. Geology, v. 4, p. 89-101.

Carter, R. W. G., and Orford, J. D., 1981, Overwash processes along a gravel beach in South-East Ireland. Earth Surface Processes and Landforms, v. 6, p. 413-426.

Cloud, P. E., 1952, Preliminary report on the geology and marine environment of Onotoa Atoll, Gilbert Islands. Atoll Research Bull., v. 12, p. 1-73.

Deplus, C. Le Friant, A., Boudon, G., Komorowski, J.-C., Villemant, B. Harford, C. Segoufin, J., and Cheminee, J.-L., 2001, Submarine evidence for large-scale debris avalanches in the Lesser Antilles arc. Earth and Planetary Science Letters, V. 192, p. 145-157.

Depradine, C. A., 1989, Pre-1900 severe hurricanes in the Caribbean. Notes compiled for the Caribbean Meteorological Institute, St. James, Barbados.

Eaton, J. P. Richter, D. H., and Ault, W. U., 1961, The tsunami of May 23, 1960, on the island of Hawaii. Seismological Society of America Bull., v. 51, p. 135-157.

Felton, E. A., 2002, Sedimentology of rocky shorelines: 1. A review of the problem, with analytical methods, and insights gained from the Hulpoe Gravel and the modern rocky shoreline of Lanai Hawaii. Sed. Geol., v. 152, p. 221-245.

Felton, E. A., Crook, K. A. W., Keating, B. H., and Kay, E. A., 2006, Sedimentology of rocky shorelines: 4 . Coarse gravel lithofacies, molluscan biofacies, and the stratigraphic and eustatic records in the type are of the Pleistocene Hulpoe Gravel, Lanai Hawaii. Sed. Geol., v. 184, p. 1-76.

Fields, F. K., and Jordan, D. G., 1972, Storm-wave swash along the north coast of Puerto Rico. U.S. Geological Survey Hydrologic Investigations Atlas HA-430.

FitzGerald, D. M., van Heteren, S., and Montello, T. M., 1994, Shoreline processes and damage resulting from the Halloween Eve Storm of 1991 along the north and south shores of Massachusetts Bay, U.S.A. Jour. of Coastal Research, v. 10, p. 113-132.

Forbes, D. L., and Syvitski, J. P. M., 1994, Paraglacial coasts. In: Carter, R. W. G., and Woodroffe, C. D., eds., Coastal Evolution, Cambridge Univ. Press, p. 373424-302. 
Geist, E. L, and Mercado, A., 1999, Tsunamis working group report, in Seismic and tsunami hazard in Puerto Rico and the Virgin Islands. U.S. Geological Survey Open-File Report 99-353.

Goff, J., Dudley, W.C., deMaintenon, M.J., Cain, G., and Coney, J.P., 2006, The largest local tsunami in 20th century Hawaii. Mar. Geol., v. 226, p. 65-79.

Hall, A. M., Hansom, J. D., Williams, D. M., and Jarvis, J., 2006, Distribution, geomorphology, and lithofacies of cliff-top storm deposits: Examples from the high-energy costs of Scotland and Ireland. Mar. Geol., in press.

Hayne, M., and Chappell, J., 2001, Cyclone frequency during the last 5000 years at Curacoa Island, north Queensland, Australia. Paleo, v. 168, p. 207-219.

Hearty, P. J., 1997, Boulder deposits from large waves during the last interglaciation on North Eleuthera Island, Bahamas. Quaternary Research, v. 48, p. 326-338.

Inman, D. L., 1949. Sorting of sediments in the light of fluid mechanics. Jour. Sed. Petrology, v. 19, p. 51-70.

Jones, B., and Hunter, I. G., 1992, Very large boulders on the coast of Grand Cayman: The effects of giant waves on rocky coastlines. Jour. of Coastal Research, v. 8, p. 763-774.

Kelletat, D., Scheffers, A., and Scheffers, S., 2004, Holocene tsunami deposits on the Bahaman islands of Long Island and Eleuthera. Zeitschrift fur Geomorphologie, v. 48. p. 519-540.

Kirk, R. M., 1980, Mixed sand and gravel beaches; morphology, processes, and sediments. Progress in Physical Geography, v. 4, p. 189-210.

Lander, J. F., Whiteside, L. S., and Lockridge, P. A., 2002. A brief history of tsunamis in the Caribbean. Science of Tsunami Hazards, v. 20, p. 57-94.

Lorang, M., 2000, Predicting threshold entrainment mass for a boulder beach. Jour. of Coastal Research, v. 16, p. 432-445.

Maragos, J. E., Baines, G. B. K., and Beveridge, P. J., 1973, Tropical Cyclone Bebe creates a new land formation on Funafuti Atoll. Science, v. 181, p. 1161-1164.

McCann, W. R., 2006, Estimating the threat of tsunamigenic earthquakes and earthquake induced-landslide tsunami in the Caribbean. In: Mercado-Irizarry, A., and Liu, P., eds., Caribbean tsunami hazard. World Scientific Publishing, $p$. 43-65.

McFadgen, B.G., and Yaldwyn, J.C., 1984, Holocene sand dunes on Enderby Island, Auckland Islands. New Zealand Journal of Geology \& Geophysics, v. 27, p. 27-33.
McKee, E.D., 1959, Storm sediments on a Pacific atoll. Jour. Sed. Petrology, v. 29, p. 354-364.

McLean, R. F., and Hosking, P. L., 1991, Geomorphology of reef islands and atoll motu in Tuvalu. South Pacific Journal of Natural Sciences, v. 11, p. 167-189.

McLean, R. F., and Woodroffe, C. D., 1994, Coral atolls. In: Carter, R. W. G., and Woodroffe, C. D., eds., Coastal Evolution, Cambridge Univ. Press, p. 267-302.

Mercado, A., and McCann, W., 1998, Numerical simulation of the 1918 Puerto Rico tsunami. Natural Hazards, v. 18, p. 57-76.

Milne, G. A., Long, A. J., and Bassett, S. E., 2005, Modeling Holocene relative sea-level observations from the Caribbean and South America. Quaternary Science Reviews, v. 24, p. 1183-1202.

Mitrovica, J. X., and Milne, G. A., 2002, On the origin of late Holocene sea-level highstands within equatorial ocean basins. Quaternary Science Reviews, v. 21, p. 2179-2190.

Moore, A., and Yoshida, I., 2001, Reappraisal of the maximum runup of the 1771 Meiwa tsunami on Ishigakyima. Disaster Control Research Center, Tohoku University, p. 53-60.

Moore, G.W., and Moore, J.G., 1988, Large-scale bedforms in boulder gravel produced by giant waves in Hawaii. In: Clifton, H.E., ed., Sedimentologic consequences of convulsive geologic events. Geol. Soc. America Spec. Paper 229, p. 101-110.

Morton, R. A., Gelfenbaum, G., and Jaffe, B. J., in press, Physical criteria for distinguishing sandy tsunami and storm deposits using modern examples. Sedimentary Geology Special Issue.

Moya, J. C., and Mercado, A., 2006, Geomorphologic and stratigraphic investigations on historic and pre-historic tsunami in northwestern Puerto Rico: Implications for long term coastal evolution. In: Mercado-Irizarry, A., and Liu, P., eds., Caribbean tsunami hazard. World Scientific Publishing, p. 149-177.

Neal, A., Richards, J., and Pye, K., 2003, Sedimentology of coarse-clastic beach-ridge deposits, Essex, southeast England. Sed. Geol., v. 162, p. 167-198.

Newell, N. D., 1954, Reefs and sedimentary processes of Raroia. Atoll Research Bull., v. 36, p. 1-32.

NOAA, 2006, URL http://hurricane.csc.noaa.gov/hurricanes/ viewer.html

Noormets, R., Felton, E. A., and Crook, K. A. W., 2002, Sedimentology of rocky shoreline: 2. Shoreline megaclasts on the north shore of Oahu, Hawaii - origins and history. Sed. Geol., v. 150, p. $31-45$. 
Noormets, R., Crook, K. A. W., and Felton, E. A., 2004, Sedimentology of rocky shoreline: 3 . Hydrodynamics of megaclast emplacement and transport on a shore platform, Oahu Hawaii. Sed. Geol., v. 172, p. 41-65.

Nott, J., 1997, Extremely high-energy wave deposits inside the Great Barrier reef, Australia: determining the cause - tsunami or tropical cyclone. Mar. Geol., v. 141, p. 193-207.

Nott, J., 2003, Waves, coastal boulder deposits and the importance of the pre-transport setting. Earth and Planetary Science Letters, v. 210, p. 269-276.

Oak, H. L., 1984. The boulder beach; a fundamentally distinct sedimentary assemblage. Annals of the Association of American Geographers, v.74, p.71-82.

Orford, J.D., Carter, R. W. G., and Jennings, S.C., 1991, Coarse clastic barrier environments: Evolution and implications for Quaternary sea level interpretations. Quaternary International, v. 9, p. 87-104.

Orford, J.D., Forbes, D.L., and Jennings, S.C., 2002, Organizational controls, typologies, and time scales of paraglacial gravel-dominated coastal systems. Geomorphology, v. 48, p. 51-85.

Pararas-Carayannis, G., 2004, Volcanic tsunami generating source mechanisms in the Eastern Caribbean region. Science of Tsunami Hazards, v. 22, p. 74-114.

Reid, H. and Taber, S., 1919, The Puerto Rico earthquake of 1918 with descriptions of earlier earthquakes. House of Representatives Document 269, Washington D.C., 74p.

Richmond, B. M., 1992, Development of atoll islets in the central Pacific. Proceedings of the 7th International Coral Reef Symposium, Guam, v. 2, p. 1185-1194.

Robinson, E., Rowe, D.-A., and Khan, S., 2006, Wave-emplaced boulders on Jamaica's rocky shore. Abst. First International Tsunami Field Symposium, Bonaire.

Rodríguez, R. W., Webb, R. M. T., and Bush, D. M., 1994, Another look at the impact of Hurricane Hugo on the shelf and coastal resources of Puerto Rico, U.S.A.: Jour. Coastal Research, v. 10, p. 278-296.

Saintilan, N., and Rogers, K., 2005, Recent storm boulders on the Beecroft Peninsula, New South Wales, Australia. Geographical Research, v. 43, p. 429-432.

Scheffers, A., 2002, Paleotsunami evidences from boulder deposits on Aruba, Curacao, and Bonaire. Science of Tsunami Hazards, v. 20, p. 26-37.
Scheffers, A., 2004, Tsunami imprints on the leeward Netherlands Antilles (Aruba, Curacao, Bonaire) and their relation to other coastal problems. Quaternary International, v. 120, p. 163-172.

Scheffers, A., 2005, Coastal response to extreme wave events - hurricanes and tsunami on Bonaire. Essener Geographische Arbeiten 37, 100p.

Scheffers, A., and Kelletat, D., 2003, Sedimentologic and geomorphologic tsunami imprints worldwide; a review. EarthScience Reviews, v. 65, p. 83-92.

Scheffers, A., and Kelletat, D., 2006, New evidence and datings of Holocene paleo-tsunami events in the Caribbean (Barbados, St. Martin, and Anguilla). In: Mercado-Irizarry, A., and Liu, P., eds., Caribbean tsunami hazard. World Scientific Publishing, p. 178-202.

Scheffers, A., Scheffers, S., and Kelletat, D., 2005, Paleo-tsunami relics on the southern and central Antillean island arc. Jour. of Coastal Research, v. 21, p. 263-273.

Schubert, C., and Valastro, S., 1976, Quaternary geology of La Orchila Island central Venezuelan offshore, Caribbean Sea. Geol. Soc. of America Bull., v. 87, p. 1131-1142.

Schubert, C., 1994, Tsunami in Venezuela: Some observations on their occurrence. In: Finkl, C. F., ed., Coastal Hazards: Perception, Susceptibility, and Mitigation. Jour. of Coastal Research Special Issue 12, p. 189-195.

Scoffin, T. P., 1993, The geological effects of hurricanes on coral reefs and the interpretation of storm deposits. Coral Reefs, v.12, p. 203-221.

Shelley, D., 1968, Fitting boulders: The result of an important shore process. Nature, v. 220, p. 1020-1021.

Simpson, R. H., and Reihl, H., 1981, The hurricane and its impact. Louisiana University Press, Baton Rouge.

Stevenson, T., 1864, The design and construction of harbours. Edinburgh, Black.

Stoddart, D. R., 1965, Re-survey of hurricane effects on the British Honduras reefs and cays. Nature, v. 207, p. 589-592.

Stoddart, D. R., 1971, Coral reefs and islands and catastrophic storms. In, Steers, J. A., ed., Applied Coastal Geomorphology, Macmillan, London, p. 155-197.

Stoddart, D. R., Woodroffe, C. D., and Spencer, 1990, Mauke, Mitiaro and Atiu: Geomorphology of Makatea Islands in the southern Cooks. Atoll Research Bull., v. 341, p. 1-65. 
Sussmilch, C. A., 1912, Notes on some recent marine erosion at Bondi. Royal Society of New South Wales Journal and Proceedings, v. 46 p.155-158.

Switzer, A D, Pucillo, K, Haredy, R. A., Jones, B. G., and Bryant, E. A., 2005, Sea level, storm or tsunami: enigmatic sand sheet deposits in a sheltered coastal embayment from southeastern New South Wales, Australia. Jour. of Coastal Research, v. 21, p. 655-663.

Taggart, B. E., Lundberg, J. L., Carew, L., and Mylroie, J. E., 1993, Holocene reef-rock boulders on Isla de Mona, Puerto Rico, transported by a hurricane or seismic sea wave. Geol. Soc. of America, Abst. with Programs v. 25, no. 6, p. 61.

Umbrove, J. H. F., 1947, Coral reefs of the East Indies. Geol. Soc. of America Bull., v. 58, p. 729-778.

Williams, A. T., and Caldwell, N. E., 1988, Particle size and shape in pebble-beach sedimentation. Mar. Geol., v. 82. p. 199-215.

Williams, D. M., and Hall, A. M., 2004, Cliff-top megaclast deposits of Ireland, a record of extreme waves in the North Atlantic - storms or tsunamis? Mar. Geol., v. 206, p. 101-117.

Woodroffe, C. D., 1994, Morphology and evolution of reef islands in the Maldives. Proc. Seventh International Coral Reef Symp., Guam, p. 1229-1238.

Zahibo, N., and Pelinovsky, E. N., 2001, Evaluation of tsunami risk in the Lesser Antilles. Natural Hazards and Earth System Sciences, v. 1, p. 221-231.

Zahibo, N., Pelinovsky, E., Okal, E., Yalciner, A., Kharif, C., Talipova, T., and Kozelkov, A., 2005, The earthquake and tsunami of November 21, 2004 at Les Saintes, Guadeloupe, Lesser Antilles. Science of Tsunami Hazards, v. 23, p. 25-39. 